\title{
Elucidating the Nature of Active Sites and
}

\section{Fundamentals for their Creation in Zn-Containing}

\section{$\mathrm{ZrO}_{2}$-Based Catalysts for Non-Oxidative Propane}

\section{Dehydrogenation}

\author{
Shanlei Hant,f, Dan Zhaot,f, Tatiana Otroshchenkoł, Henrik Lund", Ursula Bentrup ${ }^{\ddagger}$, \\ Vita A. Kondratenkoł, Nils Rockstroh $\neq$, Stephan Bartling $\neq$, Dmitry E. Doronkin ${ }^{\S}$,Jan-Dierk \\ Grunwaldt ${ }^{\S}$, Uwe Rodemerckł, David Linkeł, Manglai Gaot, Guiyuan Jiangt, ${ }^{\dagger}$ and Evgenii \\ V. Kondratenko ${ }^{\ddagger}{ }^{*}$ \\ †State Key Laboratory of Heavy Oil Processing, China University of Petroleum, Beijing, \\ Beijing, 102249, P. R. China \\ †Leibniz-Institut für Katalyse e.V. an der Universität Rostock, Albert-Einstein-Strasse 29 \\ a, D-18059 Rostock, Germany
}


§Institute of Catalysis Research and Technology and Institute for Chemical Technology and Polymer Chemistry Karlsruhe Institute of Technology (KIT) Kaiserstr. 12, 76131 Karlsruhe,

\section{Germany}

10

11

12

13

14

15

16

17

18

19

20

21

22

23

24

25

26

27

28

29

30

31

32

33

34

35

36

37

38

39

40

41

42

43

44

45

46

47

48

49

50

51

52

53

54

55

56

57

58

59

60

ACS Paragon Plus Environment 


\begin{abstract}
Environmentally friendly and low-cost catalysts are required for large-scale non-oxidative dehydrogenation of propane to propene $(\mathrm{PDH})$ to replace currently used $\mathrm{CrO}_{\mathrm{x}^{-}}$or Pt-based catalysts. This work introduces $\mathrm{ZnO}$-containing $\mathrm{ZrO}_{2}$ or $\mathrm{MZrO}_{\mathrm{x}}$-supported $(\mathrm{M}=\mathrm{Ce}$, $\mathrm{La}$, Ti or $\mathrm{Y})$ catalysts. The most active materials outperformed the state-of-the-art catalysts with supported $\mathrm{CrO}_{\mathrm{x}}, \mathrm{GaO}_{\mathrm{x}}, \mathrm{ZnO}_{\mathrm{x}}$ or $\mathrm{VO}_{\mathrm{x}}$ species as well as bulk $\mathrm{ZrO}_{2}$-based catalysts without $\mathrm{ZnO}$. The spacetime yield of propene of $1.25 \mathrm{~kg}_{\mathrm{C} 3 \mathrm{H} 6} \cdot \mathrm{kg}^{-1} \mathrm{cat}^{\cdot} \cdot \mathrm{h}^{-1}$ at a propane conversion of about $30 \%$ with propene selectivity of $95 \%$ was obtained over $\mathrm{Zn}(4 \mathrm{wt} \%) / \mathrm{TiZrO}_{\mathrm{x}}$ at $550^{\circ} \mathrm{C}$.
\end{abstract}

For deriving key insights into the structure of active sites, reactivity, selectivity and onstream stability, the catalysts were characterized by XRD, HRTEM, EDX mapping, XPS, X-ray absorption, CO-TPR, $\mathrm{CO}_{2}$-TPD, $\mathrm{NH}_{3}$-TPD, Pyridine-FTIR, operando UV-Vis spectroscopy, Raman spectroscopy, TPO and temporal analysis of products. In contrast with previous reports used bulk $\mathrm{ZrO}_{2}$-based catalysts without $\mathrm{ZnO}$, coordinatively unsaturated $\mathrm{Zr}$ cations are not the main active sites in the $\mathrm{ZnO}$-containing catalysts. Supported $\mathrm{ZnO}_{\mathrm{x}}$ species were concluded to participate in the $\mathrm{PDH}$ reaction. The current X-ray absorption analysis proved that their structure is affected by the type of metal oxide used as dopant for $\mathrm{ZrO}_{2}$ and on crystallinity of $\mathrm{ZrO}_{2}$. Isolated tricoordinated $\mathrm{Zn}^{2+}$ species 
were concluded to show high activity and on-stream stability. Their intrinsic activity is enhanced when $\mathrm{TiO}_{2}$ and $\mathrm{ZrO}_{2}$ coexist in the support or when $\mathrm{ZrO}_{2}$ is promoted by $\mathrm{TiO}_{2}$. This is probably due to accelerating hydrogen formation in the course of the $\mathrm{PDH}$ reaction as concluded from temporal analysis of products with sub millisecond resolution. The results of temperature-programmed oxidation of spent catalysts as well as ex-situ Raman and operando UV-vis studies enabled us to conclude that the high on-stream stability of isolated tricoordinated $\mathrm{Zn}^{2+}$ species is related to their low ability to form coke. In general, the tendency for coke formation seems to increase with an increase in the degree of $\mathrm{ZnO}_{\mathrm{x}}$ agglomeration.

KEYWORDS: propane dehydrogenation, selectivity, EXAFS, isolated tricoordinated $\mathrm{Zn}^{2+}$ cations, dopants, zirconia, operando UV-vis 


\section{INTRODUCTION}

Propene is one of the most important raw materials in the petroleum industry. Currently, it is mainly produced through fluid catalytic cracking $(F C C)$ and steam cracking, which suffer from both low desired selectivity and high energy consumption. ${ }^{1,2}$ Moreover, these technologies cannot completely fulfill steadily increasing demand for this olefin. ${ }^{3}$ As a consequence and owing to the exploration of shale gas containing propane, its nonoxidative dehydrogenation directly to propene draws more and more attention to close the gap between propene supply and demand. ${ }^{1,4}$ Commercially applied catalysts are supported materials on the basis of $\mathrm{Al}_{2} \mathrm{O}_{3}$ with $\mathrm{Pt}$ or $\mathrm{CrO}_{\mathrm{x}}$ species responsible for propane dehydrogenation. ${ }^{1}$

Due to the high price of platinum and environmental concerns about $\mathrm{Cr}(\mathrm{VI})$ compounds, numerous groups around the world focused their research on developing alternative catalysts with differently structured (from isolated sites to nanoclusters) supported species of various metal oxides, e.g. $\mathrm{VO}_{x}, \mathrm{GaO}_{x} \mathrm{InO}_{x}$, or $\mathrm{SnO}_{x}{ }^{5-14}$ Among such alternatives, $\mathrm{ZnO}$-based catalysts should especially be mentioned owing to the low-cost and environmentally friendly nature of this metal oxide. Both isolated $\mathrm{ZnO}_{\mathrm{x}}$ species and 
$\mathrm{ZnO}_{x}$ clusters supported on $\mathrm{SiO}_{2}$ or zeolite were reported to be active for propane dehydrogenation (PDH). ${ }^{15-18}$ Binary $\mathrm{ZnNbO}_{\mathrm{x}}$ oxides also showed high activity and selectivity. ${ }^{19}$

Recently, Kondratenko and colleagues ${ }^{20-22}$ suggested and verified a concept for designing alternative-type catalysts on the basis of $\mathrm{ZrO}_{2}$. Such materials showed industrially relevant activity and durability. Their activity and selectivity could be improved through promoting of $\mathrm{ZrO}_{2}$ with oxides of $\mathrm{La}^{3+}$ or $\mathrm{Y}^{3+}$ or through depositing tiny amounts of metallic $\mathrm{Cu}, \mathrm{Rh}$ or Ru species. ${ }^{20-22}$ The crystallite size and the phase composition (monoclinic versus tetragonal) of bare $\mathrm{ZrO}_{2}$ are also decisive factors for catalyst activity. ${ }^{23,24}$ According to DFT calculations, two neighboring coordinately unsaturated $\mathrm{Zr}$ cations $\left(\mathrm{Zr}_{\text {cus }}\right)$ were concluded to form the active site.

A synergy effect between $\mathrm{Zr}_{\text {cus }}$ and $\mathrm{CrO}_{\mathrm{x}}$ in terms of activity was established for bulk binary $\mathrm{CrZrO}_{\mathrm{x}}$ catalysts ${ }^{25}$ and their supported counterparts. ${ }^{26}$ These both systems performed superior to an analogue of commercial $\mathrm{K}-\mathrm{CrO}_{x} / \mathrm{Al}_{2} \mathrm{O}_{3}$. The ability of $\mathrm{CrO}_{\mathrm{x}}$ to promote removal of lattice oxygen form $\mathrm{ZrO}_{2}$ and to affect the intrinsic activity of $\mathrm{Zr}_{\text {cus }}$ was suggested to be responsible for the synergy effect. ${ }^{26}$ Although the amount of $\mathrm{CrO}_{x}$ in 
these catalysts was significantly reduced in comparison with $\mathrm{K}-\mathrm{CrO} / \mathrm{Al}_{2} \mathrm{O}_{3}$, they are still environmentally harmful.

Stimulated by the $\mathrm{PDH}$ performance of $\mathrm{ZrO}_{2}$-based ${ }^{20,22-24,27,28}$ or $\mathrm{ZnO}$-containing ${ }^{15,17-}$ $19,29,30$ catalysts and their environmental compatibility, the general purpose of our present study was to elucidate the potential application of catalysts composed of these metal oxides and to check if there is a synergy effect between $\mathrm{ZnO}$ and $\mathrm{ZrO}_{2}$ and/or the kind of metal (M) oxide in $\mathrm{MZrO}_{\mathrm{x}}$. From a scientific viewpoint, we focused on (i) identifying the kind of active sites, (ii) understanding the fundamentals for their formation and (iii) factors affecting product selectivity including coke formation and catalyst on-stream stability. To this end, we applied complementary characterization techniques such as X-ray absorption, infrared and Raman spectroscopy, transmission electron microscopy with energy-dispersive $\mathrm{X}$-ray spectroscopy, $\mathrm{XPS}, \mathrm{XRD}, \mathrm{NH}_{3}$-TPD, CO-TPR. For analyzing coke formation and removal, ex situ Raman, operando UV-vis spectroscopy and temperature-programmed oxidation of spent catalysts were used. Catalyst activity, selectivity, on-stream stability and durability were determined under industrially relevant 
reaction conditions. Mechanistic and kinetic details of product formation were derived from temporal analysis of products.

\section{EXPERIMENTAL}

Catalyst preparation. $\mathrm{Zn}\left(\mathrm{NO}_{3}\right)_{2} \cdot 6 \mathrm{H}_{2} \mathrm{O}$ (Merck, 98\%), $\mathrm{La}\left(\mathrm{NO}_{3}\right)_{3} \cdot 6 \mathrm{H}_{2} \mathrm{O}$ (Merck, 99\%),

$\mathrm{Y}\left(\mathrm{NO}_{3}\right)_{3} \cdot 6 \mathrm{H}_{2} \mathrm{O}$ (Sigma Aldrich, 99.9\%), $\mathrm{Ce}\left(\mathrm{NO}_{3}\right)_{3} \cdot 6 \mathrm{H}_{2} \mathrm{O}$ (Alfa Aesar, 99.5\%) and $\mathrm{ZrO}\left(\mathrm{NO}_{3}\right)_{2} \cdot \mathrm{xH}_{2} \mathrm{O}$ (Sigma Aldrich, 99\%) were used for synthesis of $\mathrm{Zn}$-containing catalysts.

$\mathrm{ZrO}_{2}$ (Daiichi Kigenso Kagaku Kogyo Co), LaZrO $\left(9 \% \mathrm{La}_{2} \mathrm{O}_{3}\right.$, Daiichi Kigenso Kagaku Kogyo Co), $\mathrm{YZrO}_{\mathrm{x}}\left(14 \% \mathrm{Y}_{2} \mathrm{O}_{3}\right.$, Daiichi Kigenso Kagaku Kogyo Co), $\mathrm{TiZrO}_{\mathrm{x}}\left(30 \% \mathrm{TiO}_{2}\right.$, Daiichi Kigenso Kagaku Kogyo Co), $\mathrm{CeZrO}_{x}\left(17.4 \% \mathrm{CeO}_{2}\right.$, Saint-Gobain Norpro), $\mathrm{Al}_{2} \mathrm{O}_{3}$ (Chempur), $\mathrm{AlSiO}_{x}\left(24 \% \mathrm{Al}_{2} \mathrm{O}_{3}\right.$, Saint-Gobain NorPro), $\mathrm{TiSiO}_{x}$ (Sachtleben Chemie $\mathrm{GmbH}$ ), R- $-\mathrm{TiO}_{2}$ (rutile $\mathrm{TiO}_{2}$, Sachtleben Chemie $\mathrm{GmbH}$ ) and $\mathrm{SiO}_{2}$ (Davisil Grade 643, Sigma Aldrich) were used as supports.

The catalysts were prepared through an impregnation method. Generally, a required amount of $\mathrm{Zn}\left(\mathrm{NO}_{3}\right)_{2} \cdot 6 \mathrm{H}_{2} \mathrm{O}$ was added to $8 \mathrm{~mL}$ of deionized water and stirred until the solution was homogenous. When preparing catalysts with Zn loading of 0.5 or $0.05 \mathrm{wt} \%$, 
an aqueous solution of $\mathrm{Zn}\left(\mathrm{NO}_{3}\right)_{2} \cdot 6 \mathrm{H}_{2} \mathrm{O}(0.1 \mathrm{~g} / \mathrm{mL})$ was initially prepared. An aliquot of this solution was taken for catalyst preparation. For both cases, $3 \mathrm{~g}$ of each support were then added to a $\mathrm{Zn}$-containing solution and heated to $65^{\circ} \mathrm{C}$ under continuous stirring until the suspension became slurry. The latter was dried at room temperature overnight, further dried at $100^{\circ} \mathrm{C}$ for $6 \mathrm{~h}$ and finally calcined at $600^{\circ} \mathrm{C}$ for $4 \mathrm{~h}$. The heating ramp was $3^{\circ} \mathrm{C} \cdot \mathrm{min}^{-1}$. $\mathrm{ZrO}_{2}, \mathrm{LaZrO}_{\mathrm{x}}, \mathrm{YZrO}_{\mathrm{x}}, \mathrm{TiZrO}_{\mathrm{x}}$ and $\mathrm{CeZrO}_{\mathrm{x}}$ were also calcined according to the same procedure. The samples were denoted as $\mathrm{yZn} / \mathrm{ZrO}_{2}(\mathrm{y}=0.05,0.5,1,2$ and 4$), 4 \mathrm{Zn} / \mathrm{LaZrO}$, $4 \mathrm{Zn} / \mathrm{YZrO}_{\mathrm{x}}, \mathrm{yZn} / \mathrm{TiZrO}_{\mathrm{x}}\left(\mathrm{y}=0.05,0.5,1,2,4,6,8,10,14\right.$ and 20), $4 \mathrm{Zn} / \mathrm{CeZrO}_{x}, 4 \mathrm{Zn} / \mathrm{Al}_{2} \mathrm{O}_{3}$ $4 \mathrm{Zn} / \mathrm{AlSiO}_{\mathrm{x}}, 4 \mathrm{Zn} / \mathrm{TiSiO}_{\mathrm{x}}, 4 \mathrm{Zn} / \mathrm{SiO}_{2}$, where 4 or $\mathrm{y}$ stand for the loading of $\mathrm{Zn}$, i.e. $4 \mathrm{wt} \%$ or $\mathrm{y} w \mathrm{w} \%$. For catalysts based on the $\mathrm{R}-\mathrm{TiO}_{2}$ support, $3 \mathrm{~g}$ of $\mathrm{R}-\mathrm{TiO}_{2}$ were used and $\mathrm{Zn}$ loading was fixed at $2 \mathrm{wt} \%$ with a mole ratio of $\mathrm{Zn}: \mathrm{M}$ of 1:2 ( $\mathrm{M}=\mathrm{La}, \mathrm{Y}, \mathrm{Ce}$ or $\mathrm{Zr}$ ). The samples were prepared according to the above-mentioned procedure. They were denoted $2 Z n / R-$ $\mathrm{TiO}_{2}, 2 \mathrm{ZnLa} / \mathrm{R}-\mathrm{TiO}_{2}, 2 \mathrm{ZnY} / \mathrm{R}-\mathrm{TiO}_{2}, 2 \mathrm{ZnCe} / \mathrm{R}-\mathrm{TiO}{ }_{2}$ and $2 \mathrm{ZnZr} / \mathrm{R}-\mathrm{TiO}_{2}$.

General Catalyst Characterization. ASAP 2020 setup (Micromeritics, USA) was used to determine the specific surface area of the catalysts and the bare supports. Nitrogen physisorption experiments were performed at $-196^{\circ} \mathrm{C}$. The BET method was applied for 
the desorption isotherm. The samples were pretreated under vacuum at $250^{\circ} \mathrm{C}$ for $2 \mathrm{~h}$ to remove adsorbed water.

Powder X-ray diffraction patterns were collected on an X'Pert Pro Theta/Theta diffractometer (Panalytical) with $\mathrm{CuK}_{\alpha}$ radiation source $(\lambda=1.5418 \AA, 40 \mathrm{kV}, 40 \mathrm{~mA})$.

Transmission electron microscopy and energy-dispersive X-ray spectroscopy were performed on a FEI F20 field emission source electron microscope equipped with a $\mathrm{LaB}_{6}$ electron gun. The accelerating voltage was $150 \mathrm{kV}$.

X-ray absorption spectra (XANES and EXAFS) at the Zn K absorption edge were recorded at the Cat-Act beamline of the KIT synchrotron (Karlsruhe) in fluorescence mode. ${ }^{31}$ The energy of the X-ray photons was selected by a Si (111) double-crystal monochromator and the beam size was set by means of slits to 1 (vertical) $\times 1.5$ (horizontal) $\mathrm{mm}^{2}$. The spectra were normalized and the extended X-ray absorption fine structure spectra (EXAFS) background were subtracted using the Athena program from the IFFEFIT software package. ${ }^{32}$ The $k^{2}$-weighted EXAFS functions were Fourier transformed $(\mathrm{FT})$ in the $\mathrm{k}$ range of $2-11 \AA^{-1}$ and multiplied by a Hanning window with sill size of $1 \AA^{-1}$. The FT EXAFS spectra were not corrected for the phase shift. In situ XANES 
measurements were carried out as follows. The $4 \mathrm{Zn} / \mathrm{TiSiO}_{x}$ catalyst (sieve fraction of $100-$ $200 \mu \mathrm{m}$ ) was loaded in an in situ micro-reactor (quartz capillary, $1.5 \mathrm{~mm}$ diameter, 0.02 $\mathrm{mm}$ wall thickness). It was heated in a flow of $20 \mathrm{vol} \% \mathrm{H}_{2}$ in $\mathrm{He}$ up to $600^{\circ} \mathrm{C}$. XANES spectra were recorded every $100^{\circ} \mathrm{C}$. Before recording the spectra, the sample was kept at each temperature for $10 \mathrm{~min}$.

For fitting the EXAFS data, the amplitude reduction factor $S_{0}^{2}=1.0$ was obtained by fitting a $\mathrm{ZnO}$ reference spectrum to a wurtzite structural model as reported in the Inorganic Crystal Structure Database (ICSD), collection code 34477. The fits were performed using Artemis $^{32}$ by a least square method in R-space between 1.0 and $3.2 \AA$. Coordination numbers, interatomic distances, energy shift $\left(\delta \mathrm{E}_{0}\right)$ and mean square deviation of interatomic distances $\left(\sigma^{2}\right)$ were refined during the fitting.

To estimate the average fraction of isolated $\mathrm{ZnO}_{x}$ species in the catalysts, we used coordination number in the second shell as follows. It was assumed that the samples contained a mixture of $\mathrm{ZnO}$ nanoparticles (visible by $\mathrm{XRD}$ ) and single isolated $\mathrm{ZnO}_{\mathrm{x}}$ species but no small $\mathrm{ZnO}_{x}$ clusters (invisible by XRD). First, Eq. (1) was used to calculate the average coordination number $\left(\mathrm{CN}(\mathrm{Zn})_{\text {average }}\right)$ of $\mathrm{Zn}$ in our samples from the respective 
EXAFS data as suggested in Ref. ${ }^{33}$ As single isolated $\mathrm{ZnO}_{\mathrm{x}}$ species do not have $\mathrm{Zn}-\mathrm{Zn}$

interaction $(\mathrm{CN}(\mathrm{Zn})=0)$, the fraction of the single sites was determined from Eq.(2).

$\mathrm{CN}(\mathrm{Zn})^{\text {average }}=\left(1-\frac{3}{4} \rho+\frac{1}{16} \rho^{3}\right) \times 12$

$\chi\left(\mathrm{Zn}^{2+}\right)=\left(1-\frac{\mathrm{CN}(\mathrm{Zn})^{\text {average }}}{12}\right)$

, where $\rho$ is the ratio of $d i / R ; d i$ and $R$ stand for distance between the shells and radius

of the nanoparticles, respectively. 12 is the coordination number of $\mathrm{Zn}$ in the perfect bulk

$\mathrm{ZnO}$.

Ex-situ XPS (X-ray Photoelectron Spectroscopy) measurements were performed on an

ESCALAB 220iXL (Thermo Fisher Scientific) with monochromatic $\mathrm{Al}$ Ka radiation $(\mathrm{E}=$

$1486.6 \mathrm{eV})$. Samples were prepared on a stainless-steel holder with conductive double-

sided adhesive carbon tape. The electron binding energies were obtained with charge

compensation using a flood electron source and referenced to the $\mathrm{C} 1 \mathrm{~s}$ core level of

adventitious carbon at $284.8 \mathrm{eV}$ (C-C and $\mathrm{C}-\mathrm{H}$ bonds).

Near-Ambient Pressure XPS (NAP-XPS - Specs GmbH) measurements were

performed at a total pressure of 2 mbar using a monochromatic Al Ka radiation source ( $E$

$=1486.6 \mathrm{eV})$. The analysis chamber was initially filled with $\mathrm{N}_{2}$ followed by feeding the 
reaction mixture (40 vol\% $\mathrm{C}_{3} \mathrm{H}_{8}$ and 5 vol\% $\mathrm{H}_{2}$ in $\mathrm{N}_{2}$ ). The sample was mounted on a stainless-steel sample plate heated by a laser heating system to $823 \mathrm{~K}$. Temperature was monitored by a thermocouple in direct contact with the sample surface. Reaction gases are monitored by a Quadrupole Mass Spectrometer (QMS - MKS e-vision 2) attached to the lens system of the spectrometer (Phoibos 150). The electron binding energies are referenced to the $\mathrm{C} 1 \mathrm{~s}$ core level of carbon at $284.8 \mathrm{eV}$ (C-C and $\mathrm{C}-\mathrm{H}$ bonds).

Temperature-programmed Methods. To determine an overall number of acidic sites and their strength, temperature-programmed desorption of ammonia $\left(\mathrm{NH}_{3}-\mathrm{TPD}\right)$ was carried out using an in house-developed set-up containing 8 fixed-bed reactors. Each fresh catalyst sample $(100 \mathrm{mg})$ was loaded into the reactor and fixed by quartz wool. It was pretreated in an air flow at $550^{\circ} \mathrm{C}$ for $1 \mathrm{~h}$ and then reduced in a flow of 50 vol\% $\mathrm{H}_{2} / \mathrm{Ar}$. Hereafter, the catalyst was cooled down in $\mathrm{Ar}$ to $120^{\circ} \mathrm{C}$ followed by feeding a mixture consisting of $1 \mathrm{vol} \% \mathrm{NH}_{3}$ in Ar with a flow rate of $10 \mathrm{~mL} \cdot \mathrm{min}^{-1}$ for $1 \mathrm{~h}$. So treated materials were purged with $\mathrm{Ar}$ for $2 \mathrm{~h}$, then cooled down to $80^{\circ} \mathrm{C}$ and kept for another $2 \mathrm{~h}$ in the same flow. In the last step, the catalyst was heated in $\mathrm{Ar}$ to $900^{\circ} \mathrm{C}$ with a ramp of $10^{\circ} \mathrm{C} \cdot \mathrm{min}^{-}$ 
1. $\mathrm{NH}$ (atomic mass unit of 15$)$ and $\mathrm{Ar}$ (atomic mass unit of 40 ) signals were recorded by an online mass spectrometer (Pfeiffer Vacuum OmniStar GSD 320).

Overall basicity of the bare supports and the catalyst with $4 \mathrm{wt} \% \mathrm{Zn}$ was determined by temperature-programmed desorption of $\mathrm{CO}_{2}$ using the same setup as for $\mathrm{NH}_{3}$-TPD measurements. $100 \mathrm{mg}$ of each fresh sample was used. The samples were heated to $550^{\circ} \mathrm{C}$ in $\mathrm{Ar}$, reduced at the same temperature in a flow of 50 vol\% $\mathrm{H}_{2}$ in $\mathrm{Ar}$ for $1 \mathrm{~h}$ and cooled down to $120^{\circ} \mathrm{C}$ in $\mathrm{Ar}$. Then they were exposed to a flow of $5 \mathrm{vol} \% \mathrm{CO}_{2}$ in $\mathrm{Ar}$ for 1 h. After purging with a flow of $\mathrm{Ar}$ for $200 \mathrm{~min}$, the samples were cooled to $30^{\circ} \mathrm{C}$ and heated to $700^{\circ} \mathrm{C}$ in $\mathrm{Ar}$ with ramp of $10^{\circ} \mathrm{C} \cdot \mathrm{min}^{-1} . \mathrm{CO}_{2}$ desorption was measured by the mass spectrometer at atomic mass units of $44\left(\mathrm{CO}_{2}\right)$ and 40 (Ar reference).

Carbon monoxide temperature-programmed reduction (CO-TPR) tests were performed using the same setup as used for $\mathrm{NH}_{3}$-TPD measurements. $100 \mathrm{mg}$ of fresh catalyst was pretreated in air flow at $550^{\circ} \mathrm{C}$ for $1 \mathrm{~h}$ and cooled down to $40^{\circ} \mathrm{C}$ in the same atmosphere. After purging step with $\mathrm{Ar}$ for $15 \mathrm{~min}, 1 \mathrm{vol} \% \mathrm{CO}$ in $\operatorname{Ar}\left(10 \mathrm{~mL} \cdot \mathrm{min}^{-1}\right)$ was fed to the reactor. The catalyst was heated to $900^{\circ} \mathrm{C}$ with a ramp of $10^{\circ} \mathrm{C} \cdot \mathrm{min}^{-1} . \mathrm{H}_{2}$ (atomic mass unit of 2), 
$\mathrm{CO}$ (atomic mass unit of 28), $\mathrm{CO}_{2}$ (atomic mass unit of 44 ) and $\mathrm{Ar}$ (atomic mass unit of 40) signals were recorded.

Temperature-programmed oxidation (TPO) measurements using the setup for $\mathrm{NH}_{3}$ TPD measurements were carried out by heating spent catalysts (collected after time-onstream stability tests with oxidized samples as described in section "Catalytic Tests") in a flow of 5 vol\% $\mathrm{O}_{2}$ in Ar mixture with a ramp of $10^{\circ} \mathrm{C} \cdot \mathrm{min}^{-1} .50 \mathrm{mg}$ of spent sample were used. $\mathrm{CO}_{2}$ (atomic mass unit of 44) and $\operatorname{Ar}$ (atomic mass unit of 40) signals were recorded.

Optical Spectroscopy Measurements. To distinguish between Lewis and Brønsted acidic sites, IR spectra of adsorbed pyridine were recorded. The measurements were carried out in transmission mode on a Bruker Tensor 27 spectrometer equipped with a home-made reactor cell with $\mathrm{CaF}_{2}$ windows connected to a gas-dosing and evacuation system. Each catalyst sample was pressed into a self-supporting wafer with a diameter of $20 \mathrm{~mm}$ and a weight of $50 \mathrm{mg}$. Before pyridine adsorption, the catalyst was heated under vacuum up to $400^{\circ} \mathrm{C}$ and then tempered for $10 \mathrm{~min}$. After cooling to room temperature under vacuum, pyridine was adsorbed at room temperature until saturation. Then the reactor cell was evacuated for removing physisorbed pyridine. The spectra were 
collected at $150^{\circ} \mathrm{C}$. Generally, subtracted spectra were evaluated. They were obtained upon subtraction of the spectrum measured after pretreatment, i.e. before pyridine adsorption, from the respective pyridine adsorbate spectra.

Raman spectra were collected on a Renishaw inVia Raman microscope using a 633 $\mathrm{nm}$ laser with a laser power of $0.161 \mathrm{~mW}$. The spent samples (collected after time-onstream stability tests with oxidized samples as described in section "Catalytic Tests") were mounted onto object slides and an objective with a magnification of 50x was applied. To obtain a representative spectrum from a potentially inhomogeneous sample, the spectra were acquired at different points of the sample. The $I_{D} / I_{G}$ ratio, i.e. the intensity ratio of Raman bands characteristic of disordered coke and graphic coke respectively, was obtained from an average of 10 spectra collected at different positions of the sample.

Operando UV-vis spectra were collected using an Avantes spectrometer, which consists of a temperature-resistant UV-vis probe, a deuterium-halogen light source, and a CCD array detector, combined with an in-house built setup containing 5 continuous fixed-bed reactors. $\mathrm{BaSO}_{4}$ was used as white reference. The catalysts were activated in air at $550^{\circ} \mathrm{C}$ for $1 \mathrm{~h}$ and exposed to a mixture of $\mathrm{C}_{3} \mathrm{H}_{8}, \mathrm{H}_{2}$ and $\mathrm{N}_{2}\left(\mathrm{C}_{3} \mathrm{H}_{8}: \mathrm{H}_{2}: \mathrm{N}_{2}=8: 1: 11\right)$ at 
the same temperature for $1 \mathrm{~h}$. Afterwards, they were exposed to air for $30 \mathrm{~min}$ to remove coke, reduced in a flow of 50 vol\% $\mathrm{H}_{2} / \mathrm{N}_{2}$ mixture, exposed to the $\mathrm{C}_{3} \mathrm{H}_{8}: \mathrm{H}_{2}: \mathrm{N}_{2}=8: 1: 11$ mixture for another $1 \mathrm{~h}$ and then exposed to air to remove coke. Spectra for each stage were collected. The catalysts amount and the reaction gas flow were 150-270 mg and 15 $\mathrm{mL} \cdot \mathrm{min}^{-1}$ respectively to reach a similar initial propane conversion of $30 \%$. For analysis of coke formation, a relative reflectance $\left(R_{\text {rel }}\right)$ was defined as the ratio of the reflectance of catalysts with reaction-induced carbon deposits $\left(R_{D H}\right)$ to that of oxidized or reduced ones $\left(\mathrm{R}_{\mathrm{O}_{2}}\right.$ or $\left.\mathrm{R}_{\mathrm{H}_{2}}\right)$ according to Eq. (3). The relative Kubelka-Munk function $\left(F\left(R_{\text {rel }}\right)\right)$ was calculated by Eq. (4).

$\mathrm{R}_{\mathrm{rel}}=\frac{\mathrm{R}_{\mathrm{DH}}}{\mathrm{R}_{\mathrm{O}_{2}}}$ or $\mathrm{R}_{\mathrm{rel}}=\frac{\mathrm{R}_{\mathrm{DH}}}{\mathrm{R}_{\mathrm{H}_{2}}}$

$\mathrm{F}\left(\mathrm{R}_{\mathrm{rel}}\right)=\frac{\left(1-\mathrm{R}_{\mathrm{rel}}\right)^{2}}{2 \times \mathrm{R}_{\mathrm{rel}}}$

Temporal Analysis of Products. $\mathrm{H} / \mathrm{D}$ exchange and $\mathrm{C}_{3} \mathrm{H}_{8}$ dehydrogenation tests were carried out in the temporal analysis of products (TAP-2) reactor. It is a pulse technique with a time resolution of approximately $100 \mu \mathrm{s}^{34,35} \mathrm{~A}$ fresh catalyst $\left(4 \mathrm{Zn} / \mathrm{ZrO}_{2}\right.$ or $4 \mathrm{Zn} / \mathrm{TiZrO}_{\mathrm{x}}$ ) sample $(41 \mathrm{mg}$, fraction of $315-710 \mu \mathrm{m})$ was packed between two layers of 
quartz particles (fraction of 250-355 $\mu \mathrm{m}$ ) in the isothermal zone of a home-made quartz reactor (inner diameter: $6 \mathrm{~mm}$, length: $40 \mathrm{~mm}$ ). Prior to the experiments, each catalyst was treated as follows. Firstly it was heated up to $550^{\circ} \mathrm{C}$ in $\mathrm{N}_{2}$ flow $\left(4 \mathrm{~mL} \cdot \mathrm{min}^{-1}\right)$, then oxidized in a mixture of $\mathrm{O}_{2}\left(2 \mathrm{~mL} \cdot \mathrm{min}^{-1}\right)$ and $\mathrm{N}_{2}\left(4 \mathrm{~mL} \cdot \mathrm{min}^{-1}\right)$ for $1 \mathrm{~h}$. Hereafter, the reactor was flushed in $\mathrm{N}_{2}$ flow $\left(4 \mathrm{~mL} \cdot \mathrm{min}^{-1}\right.$ ) for $15 \mathrm{~min}$ followed by feeding a flow of 50 vol\% $\mathrm{H}_{2}$ in $\mathrm{N}_{2}\left(4 \mathrm{~mL} \cdot \mathrm{min}^{-1}\right)$ for $1 \mathrm{~h}$ and flushing again in $\mathrm{N}_{2}$ flow $\left(4 \mathrm{~mL} \cdot \mathrm{min}^{-1}\right)$ for $15 \mathrm{~min}$. Finally, the reactor was evacuated to ca. $10^{-5} \mathrm{~Pa}$. Hereafter, pulse experiments with $D_{2} / A r=1 / 1$ or $\mathrm{C}_{3} \mathrm{H}_{8} / \mathrm{Ar}=1 / 1$ were performed at $550^{\circ} \mathrm{C}$.

The feed mixtures were prepared using $\mathrm{D}_{2}$ (CK Special Gases Limited, N2.8), $\mathrm{C}_{3} \mathrm{H}_{8}$ (Linde, 3.5) and $\operatorname{Ar}$ (Air Liquide, 5.0) without additional purification. The pulse size was up to $8 \cdot 10^{15}$ or $8 \cdot 10^{16}$ molecules per pulse in the tests with $\mathrm{D}_{2}$ or $\mathrm{C}_{3} \mathrm{H}_{8}$, respectively. The feed components and the reaction products were quantitatively analyzed by an online quadrupole mass spectrometer (HAL RC 301, Hiden Analytics). The following AMUs were used for mass spectrometric analysis: $44.0\left(\mathrm{C}_{3} \mathrm{H}_{8}\right), 42.0\left(\mathrm{C}_{3} \mathrm{H}_{8}, \mathrm{C}_{3} \mathrm{H}_{6}\right), 41.0\left(\mathrm{C}_{3} \mathrm{H}_{8}, \mathrm{C}_{3} \mathrm{H}_{6}\right)$, $30.0\left(\mathrm{C}_{3} \mathrm{H}_{8}, \mathrm{C}_{2} \mathrm{H}_{6}\right), 29.0\left(\mathrm{C}_{3} \mathrm{H}_{8}, \mathrm{C}_{2} \mathrm{H}_{6}\right), 28.0\left(\mathrm{C}_{3} \mathrm{H}_{8}, \mathrm{C}_{2} \mathrm{H}_{6}, \mathrm{C}_{2} \mathrm{H}_{4}\right), 27,0\left(\mathrm{C}_{3} \mathrm{H}_{8}, \mathrm{C}_{3} \mathrm{H}_{6}\right), 16.0$ $\left(\mathrm{CH}_{4}\right), 4.0\left(\mathrm{D}_{2}\right), 3.0(\mathrm{HD}), 2.0\left(\mathrm{H}_{2}\right)$ and $40.0(\mathrm{Ar})$. For each AMU, the pulses were repeated 
10 times and averaged to improve the signal-to-noise ratio. The fraction of formed HD was calculated from the areas of signals recorded at the respective AMUs. For better comparison of the relative response position of substances differing in their molecular weights like $\mathrm{C}_{3} \mathrm{H}_{8}$ and $\mathrm{H}_{2}$, the data were transformed to dimensionless form according to Gleaves et al. ${ }^{36}$

Catalytic Continuous-flow Tests. Propene formation rate $\left(\mathrm{r}\left(\mathrm{C}_{3} \mathrm{H}_{6}\right)\right)$ calculated according to Eq. (5) was determined after $240 \mathrm{~s}$ on stream at a propane conversion below $10 \%$ at $550^{\circ} \mathrm{C}$. $50 \mathrm{mg}$ of catalyst (particle size is $315-710 \mu \mathrm{m}$ ) was loaded into a fixed-bed quartz tubular reactor, activated in air at $550^{\circ} \mathrm{C}$ for $1 \mathrm{~h}$ and then reduced in a 50 vol\% $\mathrm{H}_{2} / \mathrm{N}_{2}$ mixture at the same temperature for $1 \mathrm{~h}$. Finally, the reactor was flushed with $\mathrm{N}_{2}$ for $15 \mathrm{~min}$, and exposed to a mixture of $\mathrm{C}_{3} \mathrm{H}_{8}$ and $\mathrm{N}_{2}\left(\mathrm{C}_{3} \mathrm{H}_{8}: \mathrm{N}_{2}=2: 3\right)$ at a weight hourly space velocity with respect to propane (WHSV $\left(\mathrm{C}_{3} \mathrm{H}_{8}\right)$ ) of $34.5 \mathrm{~h}^{-1}$ with respect to fed propane. $\mathrm{Zn}$-related turnover frequency (TOF) values were calculated according to Eq. (6).

$$
\begin{aligned}
& \mathrm{r}\left(\mathrm{C}_{3} \mathrm{H}_{6}\right)=\frac{\dot{\mathrm{n}}_{\mathrm{C}_{3} \mathrm{H}_{6}}}{\mathrm{~m}_{\mathrm{Cat}}} \\
& \mathrm{TOF}_{\mathrm{Zn}}\left(\mathrm{C}_{3} \mathrm{H}_{6}\right)=\frac{\mathrm{r}\left(\mathrm{C}_{3} \mathrm{H}_{6}\right)}{\mathrm{n}_{\mathrm{Zn}} \times 60}
\end{aligned}
$$


where $\dot{n}_{\mathrm{C} 3 \mathrm{H} 6}, \mathrm{~m}_{\mathrm{Cat}}$, and $\mathrm{n}_{\mathrm{Zn}}$ stand for molar flow of $\mathrm{C}_{3} \mathrm{H}_{6}\left(\mathrm{mmol} \cdot \mathrm{min}^{-1}\right)$, catalyst amount $(\mathrm{g})$,

and concentration of $\mathrm{Zn}$ atoms in the catalyst $\left(\mathrm{mmol} \cdot \mathrm{g}^{-1}\right)$.

To compare the catalysts with respect to their time-on-stream stability, different catalyst amounts (150-270 mg, particle size is $315-710 \mu \mathrm{m})$ were used to achieve an initial propane conversion of around $30 \%$. After the catalysts were pretreated in air or 50 vol\% $\mathrm{H}_{2}$ in $\mathrm{N}_{2}$ at $550^{\circ} \mathrm{C}$ for $1 \mathrm{~h}$, they were flushed by $\mathrm{N}_{2}$ and exposed to a mixture of $\mathrm{C}_{3} \mathrm{H}_{8}, \mathrm{H}_{2}$ and $\mathrm{N}_{2}$ $\left(\mathrm{C}_{3} \mathrm{H}_{8}: \mathrm{H}_{2}: \mathrm{N}_{2}=8: 1: 11,15 \mathrm{~mL} \cdot \mathrm{min}^{-1}\right)$ at the same temperature for $1 \mathrm{~h}$.

Durability of $4 \mathrm{Zn} / \mathrm{TiZrO}_{\mathrm{x}}$ was determined in $10 \mathrm{PDH} /$ regeneration cycles with WHSV $\left(\mathrm{C}_{3} \mathrm{H}_{8}\right)$ of $4.71 \mathrm{~h}^{-1}$ at $550^{\circ} \mathrm{C}$. Each cycle contained a $\mathrm{PDH}$ stage lasted for $28 \mathrm{~min}$ and a regeneration stage by air lasted for $30 \mathrm{~min}$. The catalyst amount was $150 \mathrm{mg}$ and the reaction $\mathrm{C}_{3} \mathrm{H}_{8}: \mathrm{H}_{2}: \mathrm{N}_{2}=8: 1: 11$ mixture.

Propane conversion $\left(\mathrm{X}\left(\mathrm{C}_{3} \mathrm{H}_{8}\right)\right)$ and the selectivity to gas-phase products $(\mathrm{S}(\mathrm{i}))$ and coke (S(coke)) were calculated according to Eqs. (7)-(9), respectively. Space-time-yield of propene (STY, $\mathrm{kg}_{\mathrm{c} 3 \mathrm{H} 6} \cdot \mathrm{kg}^{-1} \mathrm{Cat} \cdot \mathrm{h}^{-1}$ ) was calculated according to Eq. (10). All the feed components and products were analyzed by an on-line GC (Agilent 6890) equipped with FID and TCD detectors. 
$\mathrm{X}\left(\mathrm{C}_{3} \mathrm{H}_{8}\right)=\frac{\stackrel{\dot{\mathrm{n}}_{\mathrm{n}_{3}} \mathrm{H}_{8}-\dot{\mathrm{n}}_{3} \mathrm{CH}_{3}}{\text { out }} \mathrm{H}_{8}}{\dot{\mathrm{n}}_{\mathrm{C}_{3}} \mathrm{H}_{8}}$

$\mathrm{S}(\mathrm{i})=\frac{\beta_{\mathrm{i}}}{\beta_{\mathrm{C}_{3} \mathrm{H}_{8}}} \times \frac{\dot{\mathrm{n}}_{\mathrm{i}}^{\text {out }}}{\dot{\mathrm{n}}_{\mathrm{C}_{3} \mathrm{H}_{8}}-\dot{\mathrm{n}}_{3} \mathrm{H}_{3} \mathrm{H}_{8}}$

$\mathrm{S}($ coke $)=1-\sum_{\mathrm{i}} \mathrm{S}(\mathrm{i})$

$\mathrm{STY}=\frac{\dot{\mathrm{n}}_{\mathrm{C}_{3} \mathrm{H}_{6}} \times \mathrm{M}_{\mathrm{C}_{3} \mathrm{H}_{6}} \times 60}{1000 \times \mathrm{m}_{\mathrm{Cat}}}$

where n் with "in" and "out" stand for the molar flow of gas phase component (mmol· $\mathrm{min}^{-}$

$\left.{ }^{1}\right)$ at the inlet and outlet, respectively. $\beta_{\mathrm{C}_{3} \mathrm{H}^{8}}$ and $\beta_{\mathrm{i}}$ represent the number of carbon atoms in $\mathrm{C}_{3} \mathrm{H}_{8}$ and product i respectively. $\mathrm{Mc}_{3} \mathrm{H}_{6}$ is the molecular weight of propene $\left(42 \mathrm{~g} \cdot \mathrm{mol}^{-1}\right)$.

\section{RESULTS AND DISCUSSION}

Phase Composition and Morphology. X-ray diffraction (XRD) analysis was performed to identify the phase composition of the bare supports and the catalysts with $\mathrm{Zn}$ loading of $4 w t \%$. The corresponding XRD patterns are shown in Figure S1 and Figure 1a. As seen in the former figure, bare $\mathrm{ZrO}_{2}$ is composed of the monoclinic phase, while the tetragonal phase was identified in $\mathrm{LaZrO}_{\mathrm{x}}, \mathrm{YZrO}_{\mathrm{x}}$ and $\mathrm{CeZrO}$. $\mathrm{No} \mathrm{La}_{2} \mathrm{O}_{3}, \mathrm{Y}_{2} \mathrm{O}_{3}$ or $\mathrm{CeO}_{2}$ phases were observed in these materials due to the formation of solid solution. This statement is supported by the fact that the tetragonal $\mathrm{ZrO}_{2}$ phase is present in $\mathrm{LaZrO}_{\mathrm{x}}$, $\mathrm{YZrO}_{\mathrm{x}}$ and $\mathrm{CeZrO}_{\mathrm{x}}$ as a result of the well-known stabilizing effect of metal oxide dopant 
on the structure of $\mathrm{ZrO}_{2} \cdot{ }^{37} \mathrm{No}$ reflections characteristic for crystalline $\mathrm{ZrO}_{2}$ could be found in the XRD pattern of non-calcined $\mathrm{TiZrO}_{x}$ (Figure S1a). The $\mathrm{TiO}_{2}$ anatase phase $\left(\mathrm{A}-\mathrm{TiO}_{2}\right)$ characterized by a reflection at $2 \theta$ of $25.3^{\circ}$ was the only crystalline phase in this sample. After calcination of $\mathrm{TiZrO}_{\mathrm{x}}$, three separate crystalline phases were identified, i.e. the $\mathrm{TiO}_{2}$ anatase as well as the monoclinic and tetragonal $\mathrm{ZrO}_{2}$ phases (Figure $\mathrm{S} 1 \mathrm{~b}$ ). This result proves that the calcination process did not result in the formation of homogeneous solid solution of the type $\mathrm{Ti}_{x} \mathrm{Zr}_{1-\mathrm{x}} \mathrm{O}_{2}$. The reason for phase separation may be too high content of $\mathrm{TiO}_{2}(30 \mathrm{wt} \%)$

The phase composition of $\mathrm{ZrO}_{2}$ in all supports except in $\mathrm{TiZrO}_{\mathrm{x}}$ did not change after deposition of $\mathrm{ZnO}$ (Figure 1a). Amorphous $\mathrm{ZrO}_{2}$ in the $\mathrm{TiZrO}_{x}$ material was transformed into the tetragonal $\mathrm{ZrO}_{2}$ phase. Such transformation can be explained by hightemperature $\left(600^{\circ} \mathrm{C}\right)$ catalyst precursor pretreatment or/and stabilizing effect of $\mathrm{ZnO}$. As concluded from the below EXAFS data (see Local Coordination Environment of $\mathrm{Zn}$ Species), Zn should be localized on the surface and not be distributed within the lattice of $\mathrm{ZrO}_{2}$. 
No reflections characteristic for any phase of $\mathrm{ZnO}$ could be identified in $4 \mathrm{Zn} / \mathrm{TiZrO}$. In contrast with this catalyst, low-intensity reflections at $2 \theta$ of $36.3^{\circ}$, which are typical for the hexagonal $\mathrm{ZnO}$, were determined in the XRD patters of all other catalysts. Thus, the presence of $\mathrm{Ti}$ in $\mathrm{ZrO}_{2}$ or the amorphous nature of the latter in the bare $\mathrm{TiZrO}_{\mathrm{x}}$ support might be important for suppressing formation of $\mathrm{ZnO}$ crystallites after catalyst calcination.

The morphology of all catalysts was analyzed by high resolution transmission electron microscopy (HRTEM). Representative HRTEM images are shown in Figure $1 \mathrm{~b}$-f and Figure S2. One can see that all the catalysts consist of irregular small crystals (clear lattice of crystalline $\mathrm{ZrO}_{2}$ for each catalyst could be seen in Figure S2) in a disordered arrangement, which leads to the formation of mesopores among them. As proven by energy dispersive X-ray element mapping (Figure S3), no ZnO aggregates could be observed in $4 \mathrm{Zn} / \mathrm{TiZrO}_{\mathrm{x}}$ that is in agreement with the XRD data (Figure 1a). 

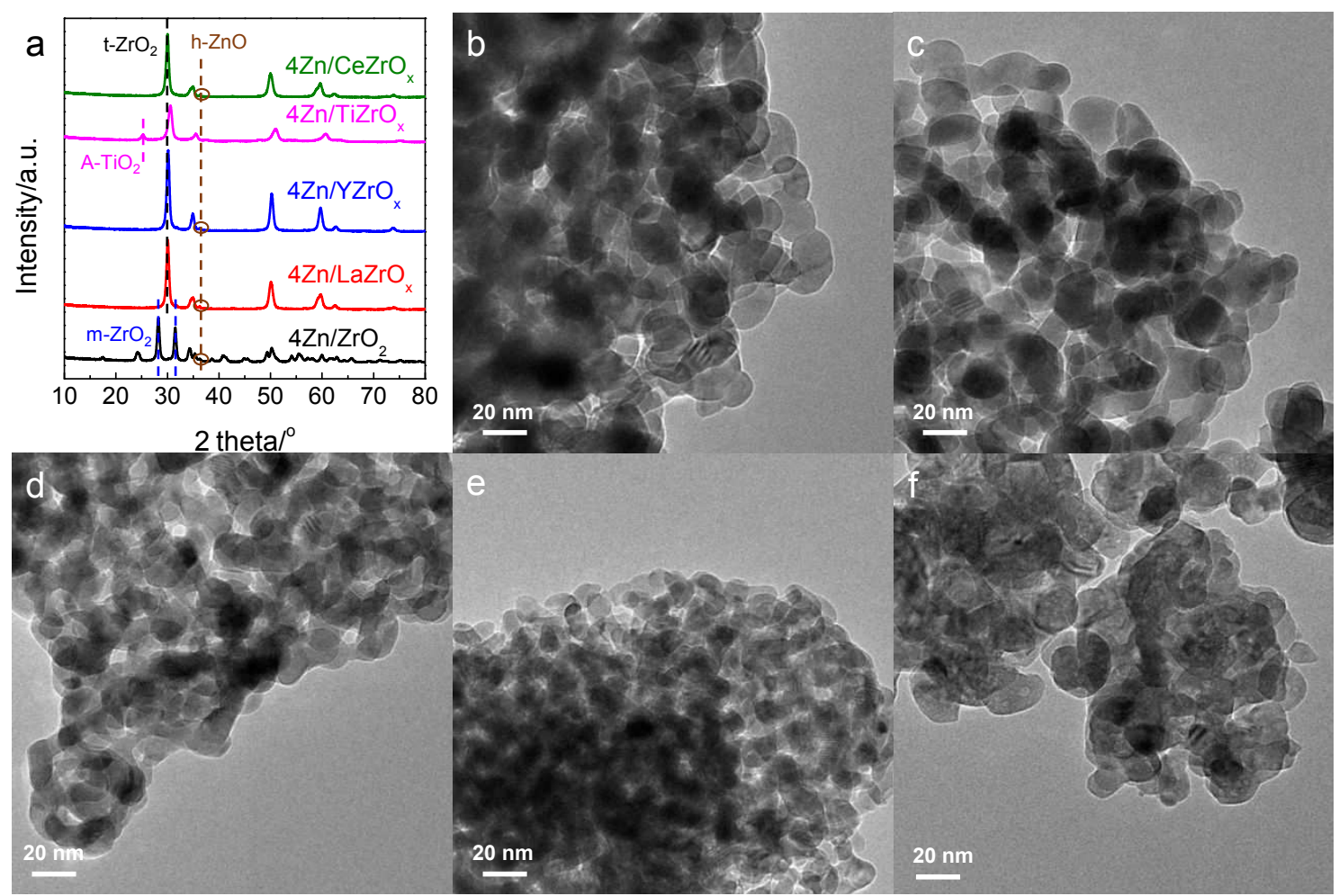

Figure 1. (a) XRD patterns and TEM images of (b) $4 \mathrm{Zn} / \mathrm{ZrO}_{2}$, (c) $4 \mathrm{Zn} / \mathrm{LaZrO}_{\mathrm{x}}$, (d) $4 \mathrm{Zn} / \mathrm{YZrO}_{\mathrm{x}}$, (e) $4 \mathrm{Zn} / \mathrm{TiZrO}{ }_{x}$, (f) $4 \mathrm{Zn} / \mathrm{CeZrO}_{\mathrm{x}}$.

Local Coordination Environment of Zn Species. Extended X-ray absorption fine structure (EXAFS) is one of the most powerful techniques for characterizing the oxidation state and local structure of Zn species. ${ }^{38}$ The Zn K-edge XANES of as-prepared Zncontaining catalysts, $\mathrm{Zn}$ foil and $\mathrm{ZnO}$ powder are presented in Figure $\mathrm{S} 4$ and $\mathrm{S} 5 \mathrm{a}$, while their Fourier-transformed $k^{2}$-weighted EXAFS (FT EXAFS) counterparts are given in Figure 2 and S5b. 
Regardless of the catalyst analyzed, $\mathrm{Zn}^{2+}$ is the only state of zinc as concluded from the shape and the position of the absorption edge in the XANES spectra. The spectra are similar to that of the $\mathrm{ZnO}$ reference (Figure S4). No signal related to metallic $\mathrm{Zn}$ could be identified in the FT EXAFS spectra of all samples (no signal at an uncorrected distance of approximately $2.2 \AA$ characteristic of metallic $Z n-Z n$ interaction). However, the catalysts differ in the average coordination numbers in the second shell $(\mathrm{Zn}-\mathrm{Zn}$ coordination as in $\mathrm{ZnO}$ ). As seen in Figure 2, only backscattering on oxygen atoms in the first-shell (uncorrected distance approx. $1.5 \AA$ ) can be observed for $\mathrm{Zn}^{2+}$ species in $4 \mathrm{Zn} / \mathrm{TiZrO}$ and no scattering at higher distances. On this basis, we can safely conclude that zinc is present in this sample in form of isolated tricoordinated $\mathrm{Zn}^{2+}$ sites (Table 1). For all other catalysts, there, however, exists ordering at higher distances. It indicates the presence of $\mathrm{ZnO}$ aggregates (Table 1). The results are consistent with the XRD data (Figure 1a). The local structure of $\mathrm{Zn}$ species in terms of average coordination number $(\mathrm{CN})$ with respect to $O$ and $Z n$ as well as the distance to $O$ and $Z n$ nearest neighbors was obtained through fitting the EXAFS data. The refined parameters are summarized in Table 1. 


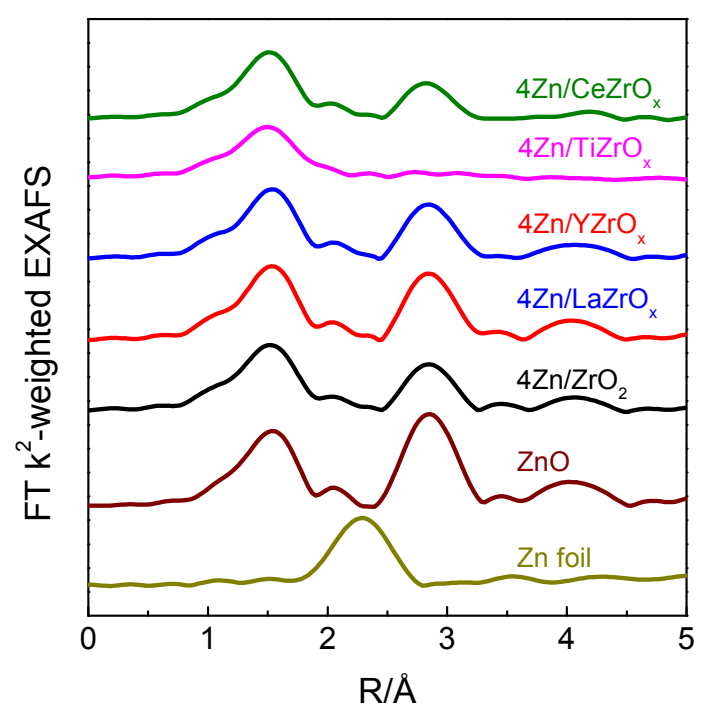

Figure 2. Fourier-transformed $\mathrm{Zn}$ K-edge EXAFS spectra of $\mathrm{Zn}$ on $\mathrm{ZrO}_{2}$-based supports, $\mathrm{Zn}$ foil and $\mathrm{ZnO}$ powder references. 
Table 1. Fraction of isolated tricoordinated $\mathrm{Zn}^{2+}$ sites $\left(\mathrm{X}\left(\mathrm{Zn}^{2+}\right)\right)$ and the coordination number $(\mathrm{CN})$ of $\mathrm{Zn}$ with respect to $\mathrm{O}$ and $\mathrm{Zn}$ neighbors determined from the analysis of EXAFS spectra as well as energy shift $\left(\delta \mathrm{E}_{0}\right)$, mean square deviation of interatomic distances $\left(\sigma^{2}\right)$ and the absolute misfit between theory and experiment $(\psi)$.

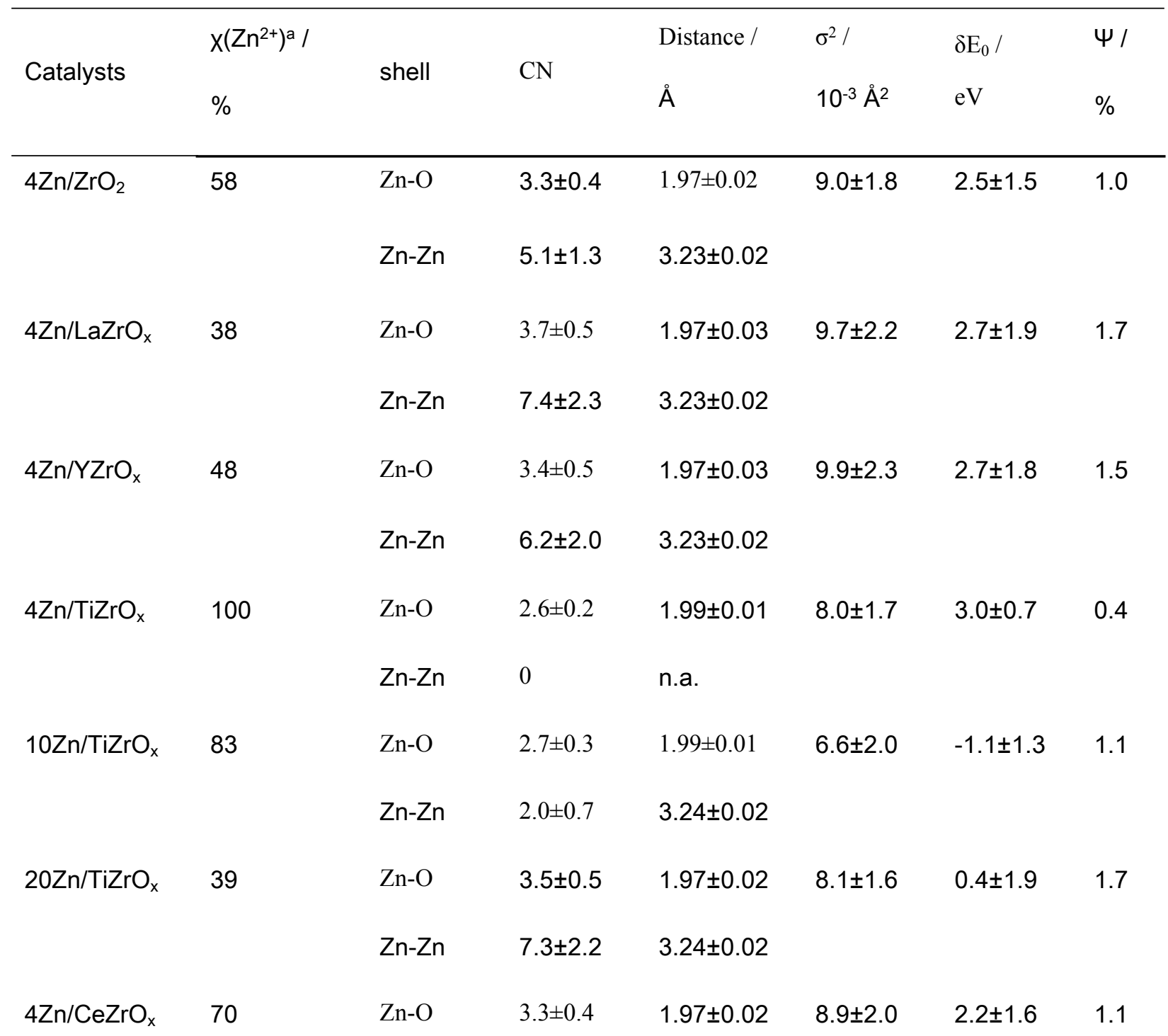


aFraction of single $\mathrm{Zn}^{2+}$ sites

From $\mathrm{CN}$ of $\mathrm{Zn}$ in the second shell (at approx. $3.23 \AA$ ), the fraction of isolated tricoordinated $\mathrm{Zn}^{2+}$ sites among total $\mathrm{ZnO}$ species was determined for each catalyst (see Eqs. 1 and 2). As can be seen in Table 1, $4 \mathrm{Zn} / \mathrm{TiZrO}_{\mathrm{x}}$ possesses exclusively isolated tricoordinated $\mathrm{Zn}^{2+}$ sites. Contrarily, both the isolated species and $\mathrm{ZnO}$ agglomerates are present in other catalysts. A relative fraction of isolated tricoordinated $\mathrm{Zn}^{2+}$ sites amounted to $58,38,48$, and $70 \%$ in $4 \mathrm{Zn} / \mathrm{ZrO}{ }_{2}, 4 \mathrm{Zn} / \mathrm{LaZrO}{ }_{x}, 4 \mathrm{Zn} / \mathrm{YZrO}_{\mathrm{x}}$ and $4 \mathrm{Zn} / \mathrm{CeZrO} \mathrm{Zr}_{\mathrm{x}}$ respectively. In comparison with $4 \mathrm{Zn} / \mathrm{TiZrO}_{\mathrm{x}}$, such fraction in $10 \mathrm{Zn} / \mathrm{TiZrO}$, and $20 \mathrm{Zn} / \mathrm{TiZrO}_{\mathrm{x}}$ is less than $100 \%$ and decreases with $\mathrm{Zn}$ loading (Table 1).

When considering the phase composition of bare supports (Figure S1), we put forward that isolation of $\mathrm{Zn}^{2+}$ upon catalyst preparation is favored when $\mathrm{ZrO}_{2}$ is X-ray amorphous. It could not be excluded that $\mathrm{A}-\mathrm{TiO}_{2}$ coexisting in the $\mathrm{TiZrO}_{\mathrm{x}}$ support may also help for dispersing $\mathrm{ZnO}$. Isolated tricoordinated $\mathrm{Zn}^{2+}$ sites could be formed upon high-temperature calcination promoting insertion of $\mathrm{Zn}^{2+}$ cations into the position of $\mathrm{Zr}^{4+}$ cation in the lattice of $\mathrm{ZrO}_{2} .^{39}$ They should, however, be located on the surface as the coordination number 
of $\mathrm{Zn}-\mathrm{O}$ first-shell is around 2.6. Thus, one single $\mathrm{Zn}^{2+}$ site is linked to three $\mathrm{O}$ atoms at a distance of about $1.99 \AA$. If $\mathrm{Zn}^{2+}$ species were in the bulk of tetragonal $\mathrm{ZrO}_{2}$, it would be coordinated by seven $\mathrm{O}$ atoms.

\section{Oxidation State of Surface Cations and Charge Transfer. X-ray photoelectron} spectroscopy (XPS) was carried out to determine the oxidation state of $\mathrm{Zn}$ and $\mathrm{Zr}$ cations and to investigate if and how the presence of $\mathrm{ZnO}$ affects electron interactions. $\mathrm{Zn}$ containing catalysts, bare $\mathrm{ZrO}_{2}$-based supports and $\mathrm{ZnO}$ were analyzed. The XP spectra related to zirconium, zinc, and oxygen are shown in Figure 3a, Figure 3b and Figure S6 respectively. We start our discussion with the spectra of zirconium in bare supports (solid lines in Figure 3a).

As seen in the XP spectra of zirconium in Figure 3a, all samples exhibit a spin-orbit doublet of the $\mathrm{Zr} 3 \mathrm{~d}$ core level into $\mathrm{Zr} 3 \mathrm{~d}_{5 / 2}$ and $\mathrm{Zr} 3 \mathrm{~d}_{3 / 2}$ with a $\mathrm{BE}$ (binding energy) of about $182.3 \mathrm{eV}$ and a splitting of $2.4 \mathrm{eV}$. Thus, the oxidation state of $\mathrm{Zr}$ should be +4.40 Furthermore, the BE value of $\mathrm{Zr} 3 \mathrm{~d}$ is influenced by the kind of metal dopant present in the bare $\mathrm{ZrO}_{2}$-based supports. For non-doped $\mathrm{ZrO}_{2}, \mathrm{LaZrO}_{\mathrm{x}}$, and $\mathrm{YZrO}_{\mathrm{x}}$ the $\mathrm{BE}$ value of $\mathrm{Zr} 3 \mathrm{~d}_{5 / 2}$ is about $182.3 \mathrm{eV}$. It lowers to 182.1 , and $182.0 \mathrm{eV}$ for $\mathrm{TiZrO}_{\mathrm{x}}$ and $\mathrm{CeZrO}_{\mathrm{x}}$ 
materials, respectively. The shift is an indication for the presence of oxygen vacancies, where electron density is mainly located. The density is also distributed to a less extent between the neighboring $\mathrm{Zr}^{4+}$ cations ${ }^{23}$ Such electron density distribution results in the shift of the $\mathrm{BE}$ value of $\mathrm{Zr} 3 \mathrm{~d}_{5 / 2}$ to lower values in comparison with bare $\mathrm{ZrO}_{2}$.
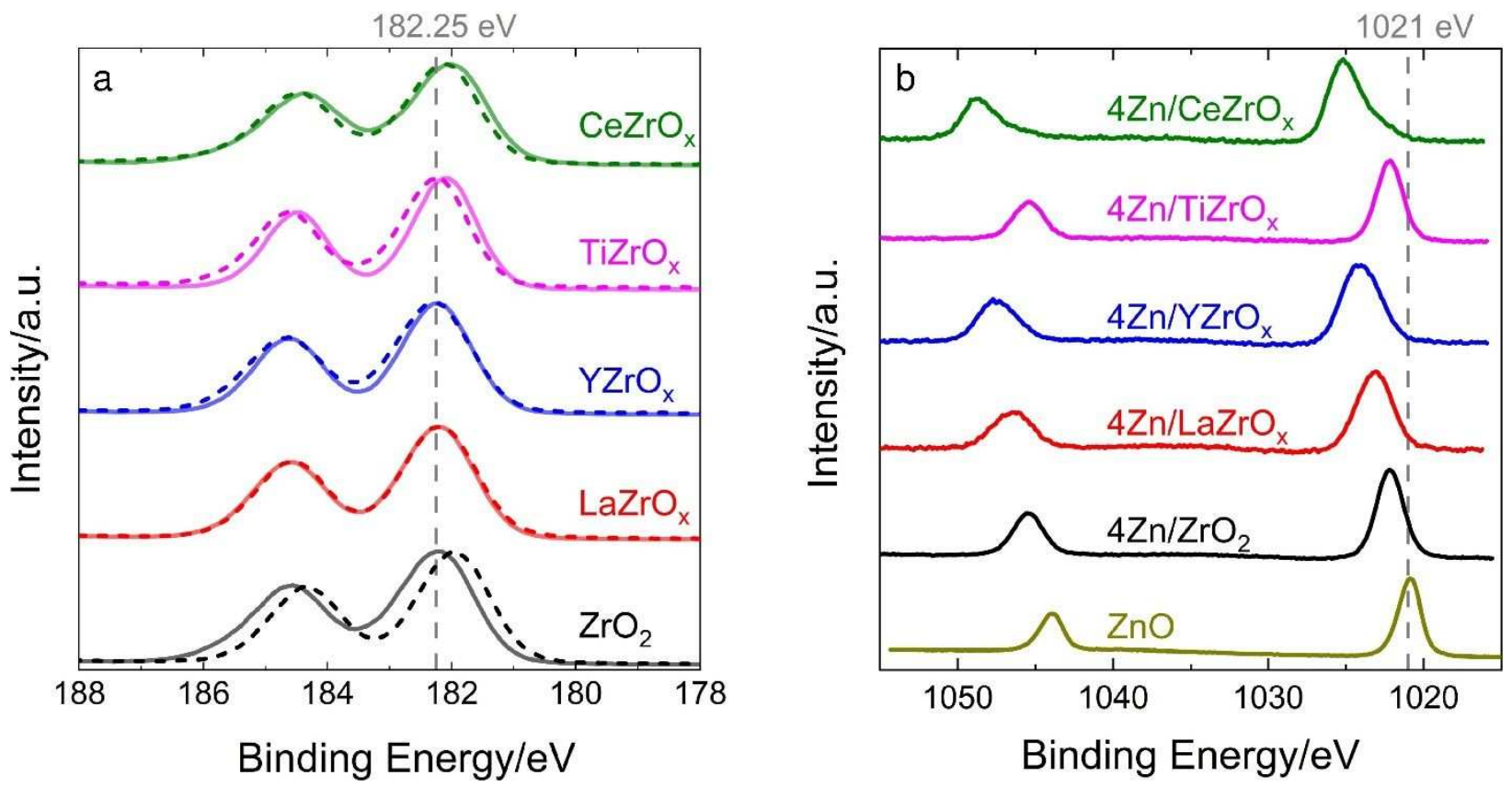

Figure 3. XP spectra of (a) $\mathrm{Zr}$ 3d (solid lines for bare $\mathrm{MZrO}_{\mathrm{x}}$ and dashed lines for $\mathrm{Zn}$ containing samples) and (b) Zn 2p in as-prepared catalysts.

It is worth mentioning that after addition of zinc, the BE value of $Z r 3 d_{5 / 2}$ shifted to slightly higher values at around $182.15 \mathrm{eV}$ (except for undoped $\mathrm{ZrO}_{2}$ ) in comparison with the bare support, while the BE values of Ti $2 p$ and Ce $3 d$, and to a minor extent of La $3 d$ and Y $3 d$ 
shifted to lower values (Figure S7). The observed higher binding energies of $Z r 3 d_{5 / 2}$ may be related to hindering the ability of $\mathrm{ZrO}_{2}$ to release its lattice oxygen in the presence of $\mathrm{ZnO}$ as proven by CO-TPR tests (see "Redox Properties", Table 2). In general, the above shifts in the BE energies of all metals prove that there is an interaction between zinc, zirconium, and the dopant cations. On the basis of previous studies with $\mathrm{ZnZrO}_{\mathrm{x}}$ materials ${ }^{42}$, the present XPS data suggest that $\mathrm{Zn}-\mathrm{O}-\mathrm{Zr}$ and/or $\mathrm{Zn}-\mathrm{O}-\mathrm{M}(\mathrm{M}=\mathrm{La}, \mathrm{Y}, \mathrm{Ti}$ and Ce) structures could be formed in our $\mathrm{Zn} / \mathrm{MZrO}$ materials. ${ }^{42}$ This statement is further supported by the following discussion of XPS results related to zinc.

The XP spectra of $Z n 2 p$ are shown in Figure $3 b$. The BE values of $Z n 2 p_{3 / 2}$ and $Z n 2 p_{1 / 2}$ in pure $\mathrm{ZnO}$ are at $1021.0 \mathrm{eV}$ and $1044.1 \mathrm{eV}$, respectively (Figure 3b, bottom graph). The spin-orbit splitting of the $\mathrm{Zn} 2 \mathrm{p}$ peaks is $23.1 \mathrm{eV}$ for all catalysts, which is characteristic for $\mathrm{ZnO} .{ }^{43}$ This is in agreement with the XANES results and we can conclude that the oxidation state of $\mathrm{Zn}$ is +2 . Importantly, for all the $\mathrm{Zn} / \mathrm{MZrO}_{x}$ catalysts, the $\mathrm{Zn} 2 \mathrm{p}$ BE is shifted by $1 \mathrm{eV}\left(4 \mathrm{Zn} / \mathrm{ZrO}_{2}\right.$ and $\left.4 \mathrm{Zn} / \mathrm{TiZrO}_{\mathrm{x}}\right)$ up to $4 \mathrm{eV}\left(4 \mathrm{Zn} / \mathrm{CeZrO}_{\mathrm{x}}\right)$ to higher values on comparison with pure $\mathrm{ZnO}$. Such behavior might suggest that $\mathrm{Zn}^{2+}$ became formally more electron deficient, i.e. electron density is transferred from $\mathrm{Zn}^{2+}$ to neighboring $\mathrm{O}^{2-}$. This 
statement is further supported by the XP spectra of $\mathrm{O} 1 \mathrm{~s}$ (especially in the case of $\mathrm{CeZrO}_{\mathrm{x}}$ )

shown in Figure S6. The BE value of $\mathrm{O}$ 1s shifted towards lower values after introducing

Zn. In addition, differential charging effects cannot be excluded and might influence the observed binding energies.

Acid-Base Properties. Overall catalyst acidity was determined by $\mathrm{NH}_{3}$-TPD tests, while

FTIR spectroscopic analysis of adsorbed pyridine was used for distinguishing between

Lewis and Brønsted sites. We shall start our discussion with the $\mathrm{NH}_{3}-\mathrm{TPD}$ data. $\mathrm{The}^{-} \mathrm{NH}_{3^{-}}$

TPD experiments were carried out over reduced samples (see "Temperature-

programmed Methods"). The obtained $\mathrm{NH}_{3}$-TPD profiles are shown in Figure S8a. Using

simple mathematical deconvolution of these profiles with Gaussian functions, three different kinds of acidic sites could be identified (Figure S9). They are characterized by the maxima of $\mathrm{NH}_{3}$ desorption at temperatures of $240-270,280-320$ and $350-395^{\circ} \mathrm{C}$, which can be ascribed to weak, medium, and strong acidic sites, respectively. Using the BET values and the amount of ammonia desorbed, we calculated an overall density of acidic sites and the density of weak, medium and strong acidic sites, which are shown in Table 
2 and Table S1. One $\mathrm{NH}_{3}$ molecule was suggested to adsorb on one acidic site. Bare $\mathrm{ZrO}_{2}$ possesses the highest density of acidic sites of $0.89 \mu \mathrm{mol}\left(\mathrm{NH}_{3}\right) \cdot \mathrm{m}^{-2}$.

Table 2. Specific surface area $\left(\mathrm{S}_{\mathrm{BET}}\right)$, $\mathrm{Zn}$ loading, the amounts of $\mathrm{NH}_{3}\left(\mathrm{n}\left(\mathrm{NH}_{3}\right)\right)$ or $\mathrm{CO}_{2}$ $\left(\mathrm{n}\left(\mathrm{CO}_{2}\right)\right)$ desorbed in $\mathrm{NH}_{3}$-TPD or $\mathrm{CO}_{2}$-TPD and the amount of $\mathrm{CO}(\mathrm{n}(\mathrm{CO}))$ consumed in CO-TPR.

\begin{tabular}{|c|c|c|c|c|c|}
\hline Catalyst & $\begin{array}{l}\mathrm{S}_{\mathrm{BET}} / \\
\mathrm{m}^{2} \cdot \mathrm{g}^{-1}\end{array}$ & $\begin{array}{l}Z n^{a} / \\
w t \%\end{array}$ & $\begin{array}{l}\mathrm{n}\left(\mathrm{NH}_{3}\right) / \\
\mu \mathrm{mol} \cdot \mathrm{m}^{-2}\end{array}$ & $\begin{array}{l}\mathrm{n}\left(\mathrm{CO}_{2}\right) / \\
\mu \mathrm{mol} \cdot \mathrm{m}^{-2}\end{array}$ & $\begin{array}{l}\mathrm{n}(\mathrm{CO}) / \\
\mu \mathrm{mol} \cdot \mathrm{g}^{-1}\end{array}$ \\
\hline $\mathrm{ZrO}_{2}$ & 33 & - & 0.89 & 0.85 & 85.9 \\
\hline $\mathrm{LaZrO}_{x}$ & 65 & - & 0.40 & 0.88 & 86.3 \\
\hline $\mathrm{YZrO}_{\mathrm{x}}$ & 68 & - & 0.54 & 0.84 & 73.9 \\
\hline $\mathrm{TiZrO}_{\mathrm{x}}$ & 77 & - & 0.76 & $4.7 \times 10^{-2}$ & 25.0 \\
\hline $\mathrm{CeZrO}_{x}$ & 40 & - & 0.71 & 0.71 & 291.9 \\
\hline $4 \mathrm{Zn} / \mathrm{ZrO}{ }_{2}$ & 43 & 3.47 & 1.0 & 1.06 & 48.4 \\
\hline $4 \mathrm{Zn} / \mathrm{LaZrO}_{\mathrm{x}}$ & 63 & 3.71 & 0.83 & 0.95 & 47.5 \\
\hline $4 \mathrm{Zn} / \mathrm{YZrO}_{\mathrm{x}}$ & 59 & 3.70 & 0.94 & 0.75 & 52.2 \\
\hline $4 \mathrm{Zn} / \mathrm{TiZrO} \mathrm{x}_{\mathrm{x}}$ & 89 & 3.75 & 1.39 & $5.4 \times 10^{-2}$ & 21.0 \\
\hline
\end{tabular}




\section{$\begin{array}{llllll}4 \mathrm{Zn} / \mathrm{CeZrO}_{x} & 44 & 3.27 & 0.71 & 0.83 & 139.1\end{array}$}

\section{aDetermined by ICP}

The density decreases after promoting $\mathrm{ZrO}_{2}$ with different metal oxides. The lowest acidic density of $0.40 \mu \mathrm{mol}\left(\mathrm{NH}_{3}\right) \cdot \mathrm{m}^{-2}$ was determined for $\mathrm{LaZrO}_{\mathrm{x}}$. In addition, the metal oxide promoter with exception of $\mathrm{CeO}_{2}$ causes a reduction of the concentration of strong and medium acidic sites (Table S1). For example, after doping with $\mathrm{La}_{2} \mathrm{O}_{3}$, the density of weak acidic sites is only 0.04 $\mu \mathrm{mol}\left(\mathrm{NH}_{3}\right) \cdot \mathrm{m}^{-2}$ lower than the corresponding value obtained for pure $\mathrm{ZrO}_{2}$, while that of medium and strong acidic sites is 0.09 and $0.35 \mu \mathrm{mol}\left(\mathrm{NH}_{3}\right) \cdot \mathrm{m}^{-2}$ lower, respectively. This result is consistent with our previous study. ${ }^{21}$

The $\mathrm{NH}_{3}$-TPD profiles of the $\mathrm{Zn}$-containing catalysts can also be deconvoluted into weak, medium or strong acidic sites which are identified by maximal temperature of $\mathrm{NH}_{3}$ desorption at $200-225,250-280$ or $335-375^{\circ} \mathrm{C}$ (Figure S9b). Compared with the bare $\mathrm{MZrO}_{\mathrm{x}}$ materials, the strength of acidic sites became weaker. However, the density of acidic sites increased significantly except for $\mathrm{CeZrO}_{\mathrm{x}}$ where it remained unchanged after loading $4 \mathrm{wt} \% \mathrm{Zn}$ (Table S1). The increased density of acidic sites could probably be assigned to surface $\mathrm{Zn}^{2+}$ species and/or newly formed unsaturated $\mathrm{Zr}^{4+}$ cations due to the incorporation of $\mathrm{Zn}^{2+}$ into the lattice of $\mathrm{ZrO}_{2}$. $4 \mathrm{Zn} / \mathrm{TiZrO}_{\mathrm{x}}$ possesses the highest acidic sites density of $1.39 \mu \mathrm{mol}\left(\mathrm{NH}_{3}\right) \cdot \mathrm{m}^{-2}$, which is about two times that of $\mathrm{TiZrO}_{\mathrm{x}}$. The lowest density of $0.71 \mu \mathrm{mol}\left(\mathrm{NH}_{3}\right) \cdot \mathrm{m}^{-2}$ was determined for $4 \mathrm{Zn} / \mathrm{CeZrO}_{\mathrm{x}}$ and is close to that of bare $\mathrm{CeZrO}_{\mathrm{x}}$.

The type (Lewis or Brønsted) of acidic sites was determined by FTIR measurements of adsorbed pyridine at $150^{\circ} \mathrm{C}$. The obtained spectra are shown in Figure 4. No Brønsted 
acidic sites could be identified in all the samples as concluded from the absence of a characteristic absorption band at around $1540 \mathrm{~cm}^{-1} .44$ For the pure supports, wellresolved bands in the region of 1442 to $1445 \mathrm{~cm}^{-1}, 1573$ to $1577 \mathrm{~cm}^{-1}$, and 1600 to 1606 $\mathrm{cm}^{-1}$ could be ascribed to pyridine bound to Lewis acidic sites. ${ }^{44,45}$ These sites should be coordinatively unsaturated $\mathrm{Zr}^{4+}\left(\mathrm{Zr}_{\text {cus }}\right)$ centers and/or $\mathrm{Ti}^{4+}\left(\mathrm{Ti}_{\text {cus }}\right)$ in the $\mathrm{TiZrO}_{\mathrm{x}}$ support. The different band positions among these supports could be due to the different strength of Lewis acidic sites as a result of electronic interactions between $\mathrm{Zr}$ cations and dopants ( $\mathrm{La}, \mathrm{Y}, \mathrm{Ti}$, and $\mathrm{Ce}$ ) (see "Oxidation State of Surface Cations and Charge Transfer"). ${ }^{46}$

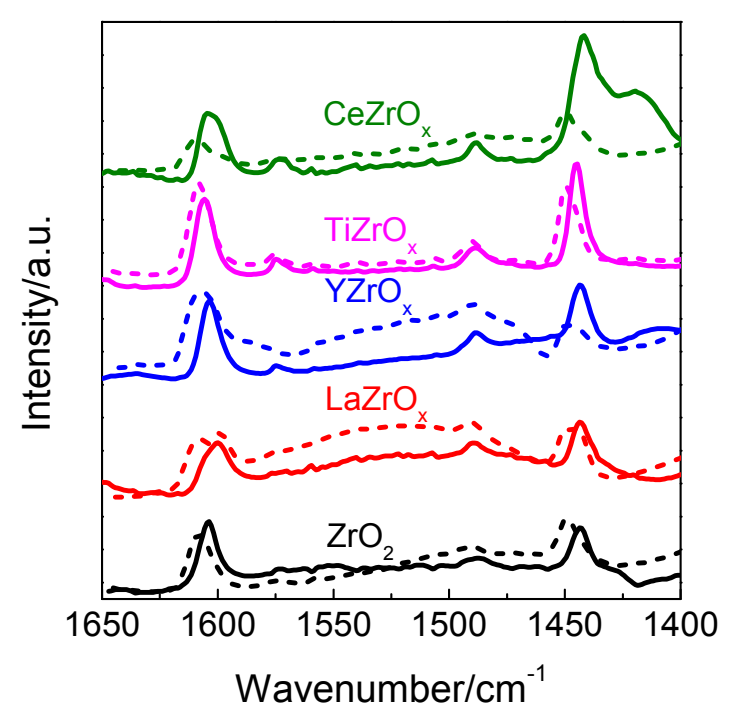

Figure 4. FTIR spectra of adsorbed pyridine over bare $\mathrm{ZrO}_{2}$-based supports (solid lines) and $\mathrm{Zn}$-containing catalysts (dash lines) at $150^{\circ} \mathrm{C}$. 
After deposition of $\mathrm{ZnO}$ species onto the supports, the above-mentioned bands shifted toward higher wavenumbers or shoulders appeared at relatively higher wavenumbers. This is due to generation of new stronger Lewis sites or increasing strength of $\mathrm{Zr}_{\text {cus }}$ acidic sites. The latter assumption is indirectly supported by the fact that, according to our XPS analysis, the $\mathrm{BE}$ value of $\mathrm{Zr} 3 \mathrm{~d} 5 / 2$ shifted to higher values after depositing $\mathrm{ZnO}$ (Figure 3a). Such shift indicates a decrease in the electronic density at $\mathrm{Zr}^{4+}$. For $4 \mathrm{Zn} / \mathrm{CeZrO}_{\mathrm{x}}$, although the density of overall acidic sites determined by means of $\mathrm{NH}_{3}$-TPD tests remained unchanged after depositing $\mathrm{ZnO}$, the intensity of bands related to adsorbed pyridine decreased in comparison with bare $\mathrm{CeZrO}_{\mathrm{x}}$. This may be due to its weak acidity (Figure S8a) and the weaker basicity of pyridine than molecular $\mathrm{NH}_{3}$. Thus, a part of adsorbed pyridine could desorb upon catalysts evacuation before the FTIR measurements. ${ }^{47}$

Surface basicity of the reduced catalysts was investigated by $\mathrm{CO}_{2}$-TPD measurements. The obtained $\mathrm{CO}_{2}$-TPD profiles are shown in Figure S10b. For bare supports, the profiles are characterized by $\mathrm{CO}_{2}$ desorption with maxima at $180-215,225-280$ and $315-350^{\circ} \mathrm{C}$ (Figure S10a). Thus, basic sites of different strength co-exist on the surface of the supports. Deconvolution of these profiles is shown in Figure S10 and the obtained fractions of each basic site are given in 
Table S2. From a quantitative viewpoint, the lowest density of basic sites of about 0.05 $\mu \mathrm{mol}\left(\mathrm{CO}_{2}\right) \cdot \mathrm{m}^{-2}$ was obtained for $\mathrm{TiZrO}_{\mathrm{x}} \cdot \mathrm{ZrO}_{2}, \mathrm{LaZrO}_{\mathrm{x}}$ and $\mathrm{YZrO}_{\mathrm{x}}$ possess significantly higher concentration of basic sites, which is about $0.85 \mu \mathrm{mol}\left(\mathrm{CO}_{2}\right) \cdot \mathrm{m}^{-2}$. A slightly lower density of 0.71 $\mu \mathrm{mol}\left(\mathrm{CO}_{2}\right) \cdot \mathrm{m}^{-2}$ was determined for $\mathrm{CeZrO}_{\mathrm{x}}$. The dopant for $\mathrm{ZrO}_{2}$ also influences the strength of basic sites. In comparison with bare $\mathrm{ZrO}_{2}$, the strength increased upon introducing $\mathrm{La}_{2} \mathrm{O}_{3}, \mathrm{Y}_{2} \mathrm{O}_{3}$ or $\mathrm{CeO}_{2}$, but decreases when $\mathrm{TiO}_{2}$ is used as dopant (Table S2).

For all Zn-containing catalysts, weak, medium and strong basic sites could also be identified with $\mathrm{T}_{\max }-\mathrm{CO}_{2}$ at $195-210,250-270$ and $330-360^{\circ} \mathrm{C}$ respectively. After deposing $\mathrm{ZnO}$, the overall density of basic sites increased for the catalysts based on $\mathrm{ZrO}_{2}, \mathrm{LaZrO}_{\mathrm{x}}$ and $\mathrm{CeZrO}_{\mathrm{x}}$ but decreased for $\mathrm{YZrO}_{\mathrm{x}}$ or remained almost unchanged for $\mathrm{TiZrO}_{\mathrm{x}}$. Adding $\mathrm{ZnO}$ mainly affected the density of weak basic sites, e.g. for $\mathrm{ZrO}_{2}$, it increased from 0.11 to $0.30 \mu \mathrm{mol}\left(\mathrm{CO}_{2}\right) \cdot \mathrm{m}^{-2}$. The strength of basic sites changed after deposition of $\mathrm{ZnO}$. It decreased for $4 \mathrm{Zn} / \mathrm{LaZrO}_{\mathrm{x}}$ but increased for all other catalysts.

Redox Properties. From our previous studies on $\mathrm{ZrO}_{2}$-based it is known that $\mathrm{Zr}_{\text {cus }}$ are the active sites for $\mathrm{PDH} .{ }^{20,23,24}$ Therefore, the reducibility of $\mathrm{ZrO}_{2}$ in differently structured bare $\mathrm{ZrO}_{2}$, $\mathrm{Ru} / \mathrm{YZrO}_{\mathrm{x}}$ or $\mathrm{Ru} / \mathrm{LaZrO}_{\mathrm{x}}$ was concluded to be of vital importance for the rate of propene formation. ${ }^{22,24,27} \mathrm{We}$ also checked if this catalyst property plays a role for the present $\mathrm{Zn}$-containing catalysts. To this end, CO-TPR tests were carried out. In contrast to typically used $\mathrm{H}_{2}$ for TPR measurements, $\mathrm{CO}$ can not only react with lattice oxygen but also remove surface hydroxyl groups producing $\mathrm{H}_{2}$ through water-gas shift reaction. ${ }^{48}$ The CO-TPR profiles obtained upon reduction of bare supports and catalysts pre-oxidized in air at $550^{\circ} \mathrm{C}$ for $1 \mathrm{~h}$ are shown in Figure 5 . CO consumption peak without $\mathrm{CO}_{2}$ formation (Figure $\mathrm{S} 11 \mathrm{a}$ ) between 320 and $365^{\circ} \mathrm{C}$ is identified for 
$\mathrm{ZrO}_{2}, \mathrm{LaZrO}_{\mathrm{x}}$ and $\mathrm{YZrO}_{\mathrm{x}}$, and could be due to $\mathrm{CO}$ chemisorption leading to the formation of formate, carbonate or carboxylate-type species. ${ }^{49} \mathrm{~A}$ broad peak at higher temperatures could be assigned to the reaction of $\mathrm{CO}$ with surface hydroxyls and/or lattice oxygen resulting in the formation of $\mathrm{CO}_{2}$ and $\mathrm{H}_{2}$. The amount of $\mathrm{CO}$ consumed by $\mathrm{ZrO}_{2}, \mathrm{YZrO}_{\mathrm{x}}$ and $\mathrm{LaZrO}_{\mathrm{x}}$ was about $100 \mu \mathrm{mol}(\mathrm{CO}) \cdot \mathrm{g}^{-1}$ (Table 2). As $\mathrm{CO}$ consumption and $\mathrm{H}_{2}$ formation occurred at almost the same temperature (Figure 5 and Figure $\mathrm{S} 11 \mathrm{~b}$ ), it can be suggested that $\mathrm{CO}$ mainly reacted with surface hydroxyls. ${ }^{50}$

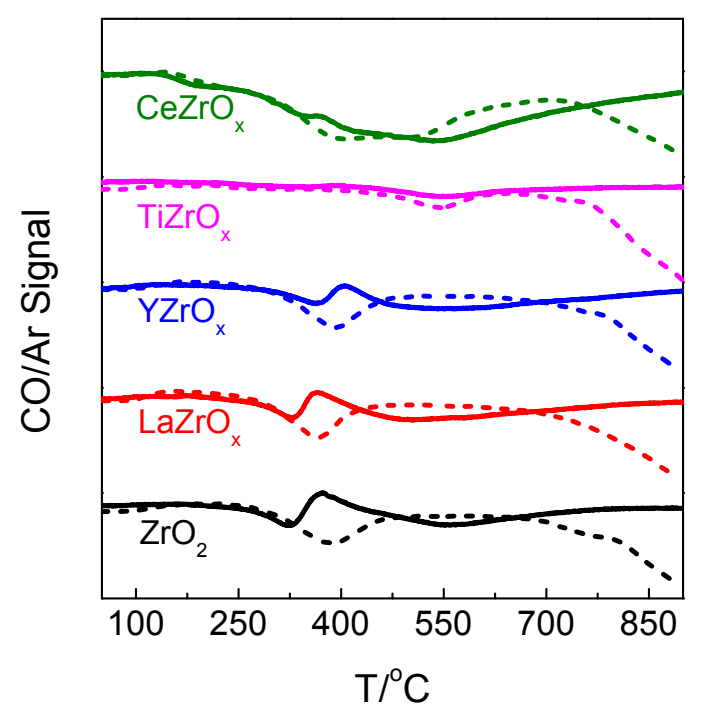

Figure 5. CO-TPR profiles of $\mathrm{ZrO}_{2}$-based supports (solid lines) and $\mathrm{Zn}$-containing catalysts (dash lines).

In comparison with $\mathrm{ZrO}_{2}, \mathrm{YZrO}_{\mathrm{x}}$ and $\mathrm{LaZrO}_{\mathrm{x}}$, no irreversible $\mathrm{CO}$ adsorption $(\mathrm{CO}$ consumption without formation of gas-phase products) was observed for $\mathrm{TiZrO}_{\mathrm{x}}$. CO consumption through reaction with lattice oxygen or hydroxyl groups was also very low, i.e. only $25.0 \mu \mathrm{mol}(\mathrm{CO}) \cdot \mathrm{g}^{-1}$. $\mathrm{CeZrO}_{x}$ exhibited the highest reducibility of $291.9 \mu \mathrm{mol}(\mathrm{CO}) \cdot \mathrm{g}^{-1}$ among the bare supports. 
This amount is about three times higher than that consumed by $\mathrm{ZrO}_{2}$. In addition, $\mathrm{H}_{2}$ formation (Figure $\mathrm{S} 11 \mathrm{~b}$ ) had a maximum at $412^{\circ} \mathrm{C}$, while the maximum of $\mathrm{CO}$ consumption is at about $543^{\circ} \mathrm{C}$ (Figure 5). Thus, the reduction process of $\mathrm{CeZrO}_{\mathrm{x}}$ could be divided into two parts, the first step is the removal of surface hydroxyls followed by reaction of bulk lattice oxygen. ${ }^{51}$

When $\mathrm{ZnO}$ (4 wt\%) was deposited on the surface of $\mathrm{MZrO}_{\mathrm{x}}$, overall catalyst redox properties changed significantly. One obvious difference seen in Figure 5 and Figure S11 is the fact that no irreversible $\mathrm{CO}$ adsorption could be observed for $4 \mathrm{Zn} / \mathrm{ZrO}_{2}, 4 \mathrm{Zn} / \mathrm{LaZrO}_{\mathrm{x}}$ and $4 \mathrm{Zn} / \mathrm{YZrO}_{\mathrm{x}}$. Moreover, $\mathrm{CO}$ consumption due to its oxidation over these samples moved towards lower temperatures with $\mathrm{T}_{\max }$ values ranging from 365 to $395^{\circ} \mathrm{C}$. As previously reported by Bianchi, ${ }^{52}$ the reactivity of hydroxyl groups for their reaction with $\mathrm{CO}$ on $\mathrm{ZnO} / \mathrm{ZrO}_{2}$ is higher than that on $\mathrm{ZrO}_{2}$. The generated formates are less stable on the former material. Their fast decomposition on $\mathrm{Zn}$-containing samples could be a reason why no irreversible $\mathrm{CO}$ adsorption chemisorption was observed, and $\mathrm{CO}_{2}$ formation shifts to lower temperatures in comparison with $\mathrm{ZnO}$-free materials. For comparative purposes, we also carried out CO-TPR tests with bare $\mathrm{ZnO}$. The obtained profiles are shown in Figure S12. The intensity of CO signal decreased continuously at temperature higher than 
$705^{\circ} \mathrm{C}$ due to a complete reduction of $\mathrm{ZnO}$ to metallic $\mathrm{Zn}$. Thus, the amount of $\mathrm{CO}$ consumed by Zn-containing catalysts was calculated by integrating the CO-TPR profiles up to $700^{\circ} \mathrm{C}$ and is given in Table 2. In comparison with $4 \mathrm{Zn} / \mathrm{ZrO}_{2}, 4 \mathrm{Zn} / \mathrm{LaZrO}_{\mathrm{x}}$ and $4 \mathrm{Zn} / \mathrm{YZrO}_{\mathrm{x}}$, redox properties of $\mathrm{TiZrO}_{\mathrm{x}}$ did not significantly change after $\mathrm{ZnO}$ deposition. The amount of $\mathrm{CO}$ consumed by $4 \mathrm{Zn} / \mathrm{TiZrO}$ was $21.0 \mu \mathrm{mol}(\mathrm{CO}) \cdot \mathrm{g}^{-1}$ and only slightly lower than $25.0 \mu \mathrm{mol}(\mathrm{CO}) \cdot \mathrm{g}^{-1}$ for $\mathrm{TiZrO}_{x}$. For other $\mathrm{Zn}$-containing catalysts, this amount was about a half of that consumed by the corresponding supports.

It is worth noting that the amount of $\mathrm{H}_{2}$ produced during CO-TPR tests (Figure $\mathrm{S} 11 \mathrm{~b}$ ) becomes much higher after introducing $\mathrm{ZnO}$. In case of bulk $\mathrm{ZnO}$, surface hydroxyl groups also contribute to irreversible CO adsorption (Figure S12). In other words, the surface hydroxyls become more abundant and the removal of bulk oxygen is inhibited by introducing $\mathrm{ZnO}$.

Catalyst Activity, Selectivity and On-stream Stability. The rate of propene formation $\left(r\left(\mathrm{C}_{3} \mathrm{H}_{6}\right)\right)$ over bare supports and the corresponding $\mathrm{Zn}$-containing catalysts is shown in Figure 6a. Among all the supports, $\mathrm{ZrO}_{2}$ and $\mathrm{YZrO}_{\mathrm{x}}$ revealed the highest activity with $\mathrm{r}\left(\mathrm{C}_{3} \mathrm{H}_{6}\right)$ of about $0.35 \mathrm{mmol} \cdot \mathrm{g}^{-1} \cdot \mathrm{min}^{-1}$, while $\mathrm{TiZrO}_{\mathrm{x}}$ was the least active. These results are 
consistent with our previous work, where we showed that yttrium is an activity-enhancing dopant for $\mathrm{ZrO}_{2}$, while cerium and titanium had a negative effect. ${ }^{20}$

The rate increased significantly after depositing $\mathrm{ZnO}$ on the supports (Figure 6a). The strength of the positive effect of zinc strongly depended on the kind of support. The highest improvement was achieved in case of $4 \mathrm{Zn} / \mathrm{TiZrO}_{\mathrm{x}}$. The rate over this catalyst was about $1.09 \mathrm{mmol} \cdot \mathrm{g}^{-1} \cdot \mathrm{min}^{-1}$ and, thus, approximately 18 times higher than that over bare $\mathrm{TiZrO}_{\mathrm{x}} .4 \mathrm{Zn} / \mathrm{TiZrO}_{\mathrm{x}}$ showed the highest activity among all the catalysts tested, while $4 \mathrm{Zn} / \mathrm{CeZrO}_{x}$ was the least active. Nevertheless, for the latter catalyst, the second highest rate enhancement by the addition of $\mathrm{ZnO}$ was established (Figure S13). In general, the catalysts can be ordered in terms of the improvement of their activity through $\mathrm{ZnO}$ as follows: $4 \mathrm{Zn} / \mathrm{TiZrO}{ }_{\mathrm{x}}>4 \mathrm{Zn} / \mathrm{CeZrO}_{\mathrm{x}}>4 \mathrm{Zn} / \mathrm{LaZrO}_{\mathrm{x}}>4 \mathrm{Zn} / \mathrm{YZrO}_{\mathrm{x}}>4 \mathrm{Zn} / \mathrm{ZrO}{ }_{2}$. Mechanistic insights into the nature of active sites and the effects of metal oxide promoter for $\mathrm{ZrO}_{2}$ and the structure of $\mathrm{ZrO}_{2}$ will be discussed in section "Nature of Active Site".

To benchmark our catalysts in terms of propene productivity, we determined spacetime-yield (STY) of propene formation over the best performing $4 \mathrm{Zn} / \mathrm{TiZrO}$ catalyst at $550^{\circ} \mathrm{C}$ at a propane conversion of about $30 \%$ using an industrially relevant reaction feed with 40 
vol\% propane and 5 vol\% hydrogen in nitrogen. $\mathrm{H}_{2}$ was co-fed to mimic reaction conditions typical for Pt-based catalysts. It has, however, a negative effect of propane conversion due to the reversibility of the PDH reaction but may help to reduce coke formation. The selectivity to propene under this condition was about $95 \%$. The obtained STY value was $1.25 \mathrm{~kg}_{\mathrm{C} 3 \mathrm{H} 6} \cdot \mathrm{kg}_{\mathrm{Cat}}^{-1} \cdot \mathrm{h}^{-1}$ and is compared in Figure $6 \mathrm{~b}$ with the values reported in literature for catalysts containing supported $\mathrm{CrO}_{x}, \mathrm{GaO}_{x}, \mathrm{ZnO}_{\mathrm{x}}$ or $\mathrm{VO}_{\mathrm{x}}$ species. ${ }^{10,13,15,17,53-60}$ One can clearly see that our $4 \mathrm{Zn} / \mathrm{TiZrO} \mathrm{Z}_{\mathrm{x}}$ catalyst outperformed such materials. All previously tested $\mathrm{Zn}$-containing catalysts with even higher $\mathrm{ZnO}$ loading were less active than $4 \mathrm{Zn} / \mathrm{TiZrO}_{\mathrm{x}}$.
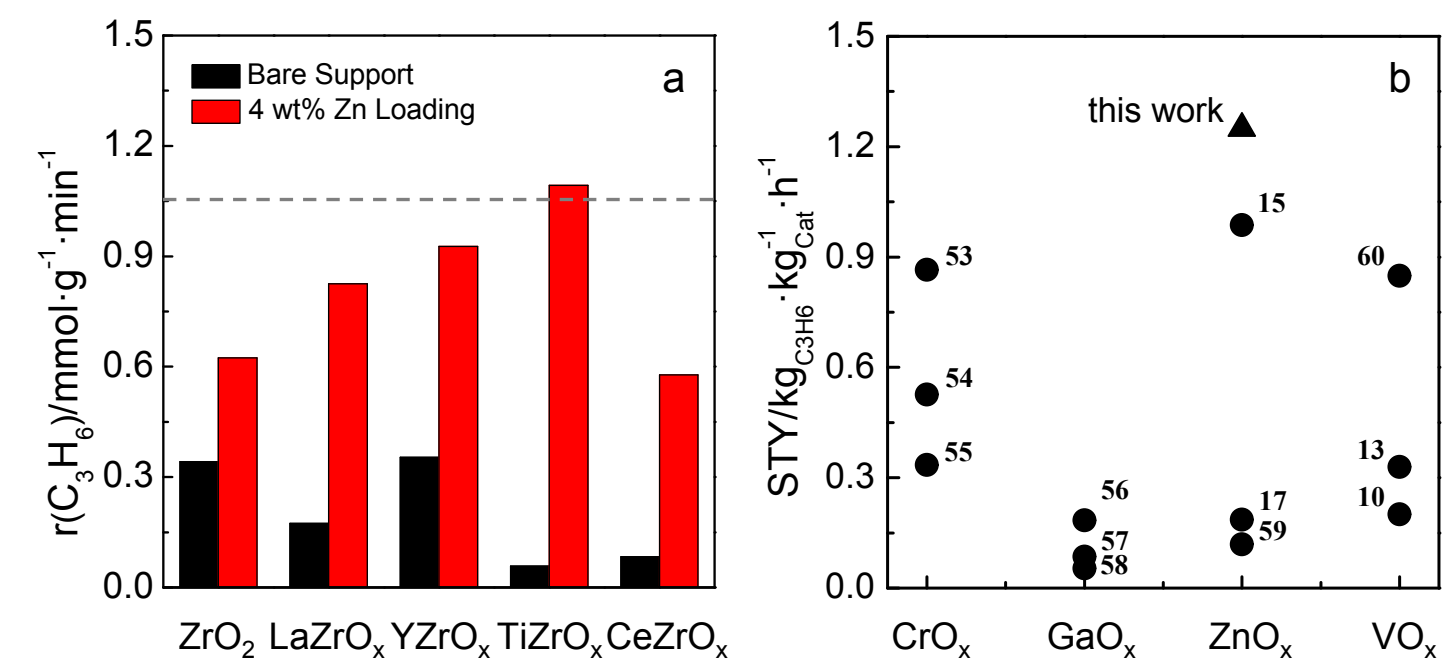

Figure 6. (a) Propene formation rate over calcined $\mathrm{ZrO}_{2}$-based supports (black bars) and corresponding Zn-containing catalysts (red bars) and (b) comparison of STY with other 
works published. The grey dash line in (a) stands for the activity of a commercial-like K$\mathrm{CrO}_{x} / \mathrm{Al}_{2} \mathrm{O}_{3}$ from Ref. ${ }^{25}$. For $\mathrm{r}\left(\mathrm{C}_{3} \mathrm{H}_{6}\right)$ test, reaction conditions: $\mathrm{T}=550^{\circ} \mathrm{C}$, catalyst amount $=50 \mathrm{mg}, \mathrm{C}_{3} \mathrm{H}_{8}: \mathrm{N}_{2}=2: 3, \mathrm{WHSV}\left(\mathrm{C}_{3} \mathrm{H}_{8}\right)=34.5 \mathrm{~h}^{-1}$, the catalysts were reduced in a flow of 50 vol\% $\mathrm{H}_{2}$ in $\mathrm{N}_{2}$ for $1 \mathrm{~h}$ at $550^{\circ} \mathrm{C}$ before reaction. For benchmarking, reaction conditions: $\mathrm{T}=550^{\circ} \mathrm{C}$, catalyst amount $=150 \mathrm{mg}, \mathrm{C}_{3} \mathrm{H}_{8}: \mathrm{H}_{2}: \mathrm{N}_{2}=8: 1: 11, \mathrm{WHSV}\left(\mathrm{C}_{3} \mathrm{H}_{8}\right)=4.71 \mathrm{~h}^{-1}$, the catalyst was initially activated in air for $1 \mathrm{~h}$ at $550^{\circ} \mathrm{C}$. Propane conversion and propene selectivity values were 30 and $95 \%$ respectively.

To check if and how the kind of support affects time-on-stream stability and selectivity to propene, we carried out a test lasting for $1 \mathrm{~h}$ on propane stream with the $4 \mathrm{Zn} / \mathrm{MZrO} \mathrm{x}_{\mathrm{x}}$ catalysts. For their fair comparison, an individual contact time was adjusted for each catalyst to achieve the initial propane conversion of about $30 \%$. Figure 7 shows time-onstream profiles of propane conversion and propene selectivity. 


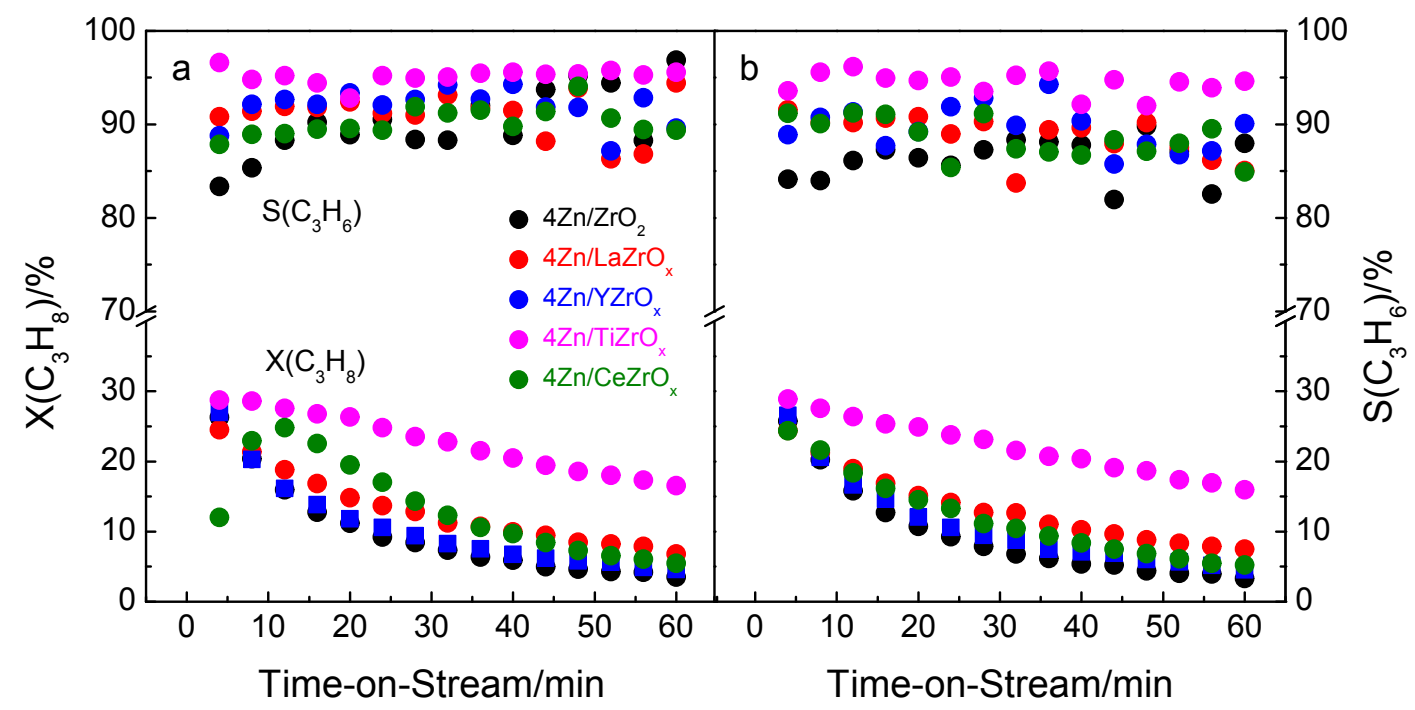

Figure 7. Catalytic performance during $1 \mathrm{~h}$ propane on-stream over (a) oxidized and (b) reduced catalysts. Reaction conditions: $\mathrm{T}=550^{\circ} \mathrm{C}$, catalyst amount $=150-270 \mathrm{mg}$, $\mathrm{C}_{3} \mathrm{H}_{8}: \mathrm{H}_{2}: \mathrm{N}_{2}=8: 1: 11, \operatorname{WHSV}\left(\mathrm{C}_{3} \mathrm{H}_{8}\right)=3.21,3.72,4.71,4.71$ and $2.62 \mathrm{~h}^{-1}$ for $4 \mathrm{Zn} / \mathrm{ZrO}_{2}(\bullet)$, $4 \mathrm{Zn} / \mathrm{LaZrO}_{\mathrm{x}}(\bullet), 4 \mathrm{Zn} / \mathrm{YZrO}_{\mathrm{x}}(\bullet), 4 \mathrm{Zn} / \mathrm{TiZrO}{ }_{\mathrm{x}}(\bullet)$ and $4 \mathrm{Zn} / \mathrm{CeZrO}_{\mathrm{x}}(\bullet)$, respectively. For oxidized catalysts, they were activated in air at $550^{\circ} \mathrm{C}$ for $1 \mathrm{~h}$. For reduced catalysts, they were pretreated in 50 vol\% $\mathrm{H}_{2}$ in $\mathrm{N}_{2}$ at $550^{\circ} \mathrm{C}$ for $1 \mathrm{~h}$ after activation in air.

Regardless of the catalyst pretreatment (reductive or oxidative), $4 \mathrm{Zn} / \mathrm{TiZrO}_{x}$ revealed the highest stability and the highest selectivity to propene. For example, the conversion over oxidized or reduced $4 \mathrm{Zn} / \mathrm{TiZrO}_{\mathrm{x}}$ decreased from $29 \%$ to $17 \%$ (Figure $7 \mathrm{a}$ ) or from $29 \%$ to $16 \%$ (Figure $7 \mathrm{~b}$ ) within $1 \mathrm{~h}$ on propane stream. The selectivity to propene was 
about $95 \%$. The fastest deactivation and the lowest selectivity to propene were determined for $4 \mathrm{Zn} / \mathrm{ZrO}_{2}$. Propane conversion decreased from $26 \%$ to $3 \%$ during $1 \mathrm{~h}$ on propane on stream. The initial selectivity to propene was about $85 \%$. One should mention that propane conversion over oxidized $4 \mathrm{Zn} / \mathrm{CeZrO}$ passed through a maximum after 12 min on propane stream, while such phenomenon was not observed for reduced $4 \mathrm{Zn} / \mathrm{CeZrO}_{\mathrm{x}}$. This could be due to the formation of new active sites by in-situ reduction of the oxidized catalyst by propane..$^{61}$

The durability of $4 \mathrm{Zn} / \mathrm{TiZrO}_{\mathrm{x}}$ was investigated in a separate test comprising of 10 PDH/oxidative regeneration cycles at $550^{\circ} \mathrm{C}$. Each cycle consisted of a PDH stage lasted for $28 \mathrm{~min}$ and a regeneration stage lasted for $30 \mathrm{~min}$. For comparative purposes, we also used catalytic data obtained over a reference $\mathrm{ZrO}_{2}$-based material $\left(\mathrm{Ru}(0.005 \mathrm{wt} \%) / \mathrm{YZrO}_{\mathrm{x}}\right)$ investigated in our previous work. ${ }^{22}$ Importantly, although the present catalyst was tested in $\mathrm{H}_{2}$ presence (negative effect of $\mathrm{H}_{2}$ on propane conversion) and at about 3 times higher WHSV $\left(\mathrm{C}_{3} \mathrm{H}_{8}\right)\left(4.71 \mathrm{~h}^{-1}\right.$ vs. $\left.1.57 \mathrm{~h}^{-1}\right)$, it showed a similar initial conversion in comparison with $\mathrm{Ru}(0.005 \mathrm{wt} \%) / \mathrm{YZrO}_{\mathrm{x}}$ (Figure 8). The selectivity to propene over $4 \mathrm{Zn} / \mathrm{TiZrO}_{\mathrm{x}}$ was 
about $8 \%$ higher than that over $\mathrm{Ru}(0.005 \mathrm{wt} \%) / \mathrm{ZrO}_{\mathrm{x}}$ at a close initial degree of propane conversion.

During the first $\mathrm{PDH}$ stage, propane conversion over $4 \mathrm{Zn} / \mathrm{TiZrO}$. decreased from $29 \%$ to $24 \%$. The conversion degree in the $10^{\text {th }}$ cycle was slightly lower, i.e. $25 \%$ and $23 \%$ at the beginning and in the end of the PDH stages respectively. The slight drop in the initial propane conversion between the $1^{\text {st }}$ and $10^{\text {th }} \mathrm{PDH}$ cycles can be ascribed to loss of $\mathrm{Zn}$. According to the ICP analysis, the fresh sample contains 4.06 and $16.70 \mathrm{wt} \%$ of $\mathrm{Zn}$ and $\mathrm{Ti}$, respectively. The corresponding loading in the spent sample is 3.34 and $17.2 \mathrm{wt} \%$. Regardless of the cycle number, the selectivity to propene was around $95 \%$. Thus, $4 \mathrm{Zn} / \mathrm{TiZrO}$ x showed good durability under industrially relevant conditions even in $\mathrm{H}_{2}$ presence.

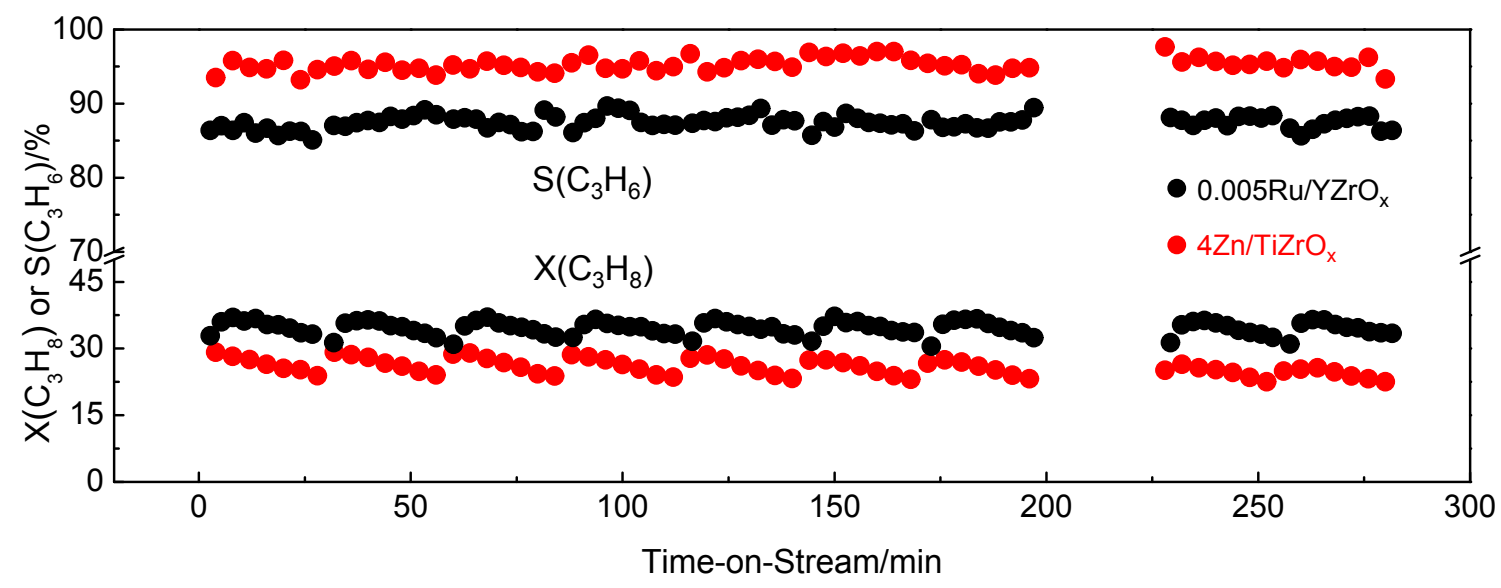


Figure 8. Propane conversion and the selectivity to propene over oxidized $4 \mathrm{Zn} / \mathrm{TiZrO}_{\mathrm{x}}(\bullet)$ and $\mathrm{Ru}(0.005 \mathrm{wt} \%) / \mathrm{YrO}_{\mathrm{x}}(\bullet)$ in $10 \mathrm{PDH} /$ regeneration cycles. The data for the latter catalyst are from our previous study. ${ }^{22}$ Reaction conditions for $4 \mathrm{Zn} / \mathrm{TiZrO}_{\mathrm{x}}: \mathrm{T}=550^{\circ} \mathrm{C}$, catalyst amount $=150 \mathrm{mg}, \mathrm{C}_{3} \mathrm{H}_{8}: \mathrm{H}_{2}: \mathrm{N}_{2}=8: 1: 11, \operatorname{WHSV}\left(\mathrm{C}_{3} \mathrm{H}_{8}\right)=4.71 \mathrm{~h}^{-1}$. Reaction conditions for $\mathrm{Ru}(0.005 \mathrm{wt} \%) / \mathrm{YZrO}_{\mathrm{x}}: \mathrm{T}=550^{\circ} \mathrm{C}$, catalyst amount $=300 \mathrm{mg}, \mathrm{C}_{3} \mathrm{H}_{8}: \mathrm{N}_{2}=2: 3$, WHSV $\left(\mathrm{C}_{3} \mathrm{H}_{8}\right)=1.57 \mathrm{~h}^{-1}$. Each cycle consisted of a PDH stage lasted for $28 \mathrm{~min}$ and a regeneration stage lasted for $30 \mathrm{~min}$.

Nature of Active Site. As proven in our previous studies with $\mathrm{Zn}$-free $\mathrm{ZrO}_{2}$-based catalysts, ${ }^{24,27}$ the ability of $\mathrm{ZrO}_{2}$ to release lattice oxygen upon reductive catalyst treatment is a decisive activity-determining factor. When lattice oxygen is removed, $\mathrm{Zr}_{\text {cus }}$ cations are formed. Two such sites form the active site for propane dehydrogenation. ${ }^{24}$ Under this consideration, if $\mathrm{Zr}_{\text {cus }}$ were also responsible for propane activation over our $\mathrm{Zn}$-containing $\mathrm{ZrO}_{2}$ - or $\mathrm{MZrO}_{x}$-supported catalysts, there should be a correlation between the rate of propene formation and reducibility. We defined the latter catalyst property as the number of $\mathrm{CO}$ molecules consumed in CO-TPR tests (Figure 5). For the bare supports, 
a rough correlation $\left(\mathrm{CeZrO}_{\mathrm{x}}\right.$ is not considered due to easy reduction of $\mathrm{CeO}_{2}$, which is however not active for the PDH reaction) between the activity and the reducibility can be deduced from Figure S14. In contrast to the bare supports, the rate of propene formation over $4 \mathrm{Zn} / \mathrm{MTiO}_{\mathrm{x}}$ decreases with catalyst reducibility. Moreover, we also established that supporting $\mathrm{ZnO}$ on $\mathrm{ZrO}_{2}$ or $\mathrm{MZrO}_{\mathrm{x}}$ inhibits the ability of $\mathrm{ZrO}_{2}$ to release its lattice oxygen (Table 2). However, the rate of propene formation over less reducible $4 \mathrm{Zn} / \mathrm{ZrO}_{2}$ and $4 \mathrm{Zn} / \mathrm{MZrO}_{\mathrm{x}}$ is higher than over the corresponding bare supports. It is also worth mentioning that the strongest effect of $\mathrm{Zn}$ on the activity rise was established for $4 \mathrm{Zn} / \mathrm{TiZrO}_{\mathrm{x}}$ and $4 \mathrm{Zn} / \mathrm{CeZrO}_{\mathrm{x}}$ possessing the highest and the second highest fraction of tricoordinated $\mathrm{Zn}^{2+} \mathrm{O}_{\mathrm{x}}$ species respectively. Another important difference between the $\mathrm{Zn}$ free and $\mathrm{Zn}$-containing $\mathrm{ZrO}_{2}$-based catalysts is the activation energy of propene formation (Figure S15). The energy is lower for the former materials.

Against the above discussion, we put forward that coordinative unsaturated $\mathrm{Zr}$ cations should not be the (only) active sites for propane dehydrogenation over the Zn-containing catalysts. Do Zn species actively participate in propane dehydrogenation? To answer this 
question, we prepared and tested additional materials. We varied $\mathrm{Zn}$ loading on $\mathrm{ZrO}_{2}$ and $\mathrm{TiZrO}_{\mathrm{x}}$ supports and the kind of support for a certain $\mathrm{Zn}$ loading.

As the first step, we analyze the effect of $\mathrm{Zn}$ loading on the rate of propene formation over $\mathrm{Zn} / \mathrm{ZrO}_{2}$ and $\mathrm{Zn} / \mathrm{TiZrO}_{\mathrm{x}}$ (Figure 9a). For the former materials, $\mathrm{Zn}$ loading less than 2 $\mathrm{wt} \%$ is detrimental to the activity, i.e. $0.5 \mathrm{Zn} / \mathrm{ZrO} \mathrm{O}_{2}$ and $1 \mathrm{Zn} / \mathrm{ZrO}_{2}$ showed the rate of 0.11 and $0.24 \mathrm{mmol} \cdot \mathrm{g}^{-1} \cdot \mathrm{min}^{-1}$ respectively versus $0.32 \mathrm{mmol} \cdot \mathrm{g}^{-1} \cdot \mathrm{min}^{-1}$ for the bare $\mathrm{ZrO}_{2}$ (Figure 6a). Their higher loaded counterparts revealed higher activity than $\mathrm{ZrO}_{2}$. Such dependence does not support the importance of $\mathrm{Zr}_{\text {cus }}$ sites for the PDH reaction, as their concentration should decreases with an increase in $\mathrm{Zn}$ loading.

In contrast to the $\mathrm{Zn} / \mathrm{ZrO}_{2}$ system, the rate of propene formation over $\mathrm{Zn} / \mathrm{TiZrO}{ }_{x}$ continuously increased with $\mathrm{Zn}$ loading up to $14 \mathrm{wt} \%$ and reached its highest value of $1.41 \mathrm{mmol} \cdot \mathrm{g}^{-1} \cdot \mathrm{min}^{-1}$. When the loading was further increased to $20 \mathrm{wt} \%$, the rate slightly decreased. Such decrease in the activity might be due to the formation of crystalline $\mathrm{ZnO}$ as proven by XRD (Figure S16a). Furthermore, the reflection related to the (101) plane of $\mathrm{t}-\mathrm{ZrO}_{2}$ shifted with increasing $\mathrm{Zn}$ loading, which suggests that $\mathrm{Zn}^{2+}$ cations were 
dissolved in the lattice of $\mathrm{ZrO}_{2}$ (Figure S16b). Although high loaded $\mathrm{Zn} / \mathrm{TiZrO}_{\mathrm{x}}$ possess crystalline $\mathrm{ZnO}$, there are also isolated $\mathrm{ZnO}_{\mathrm{x}}$ species on the surface (Table 1).
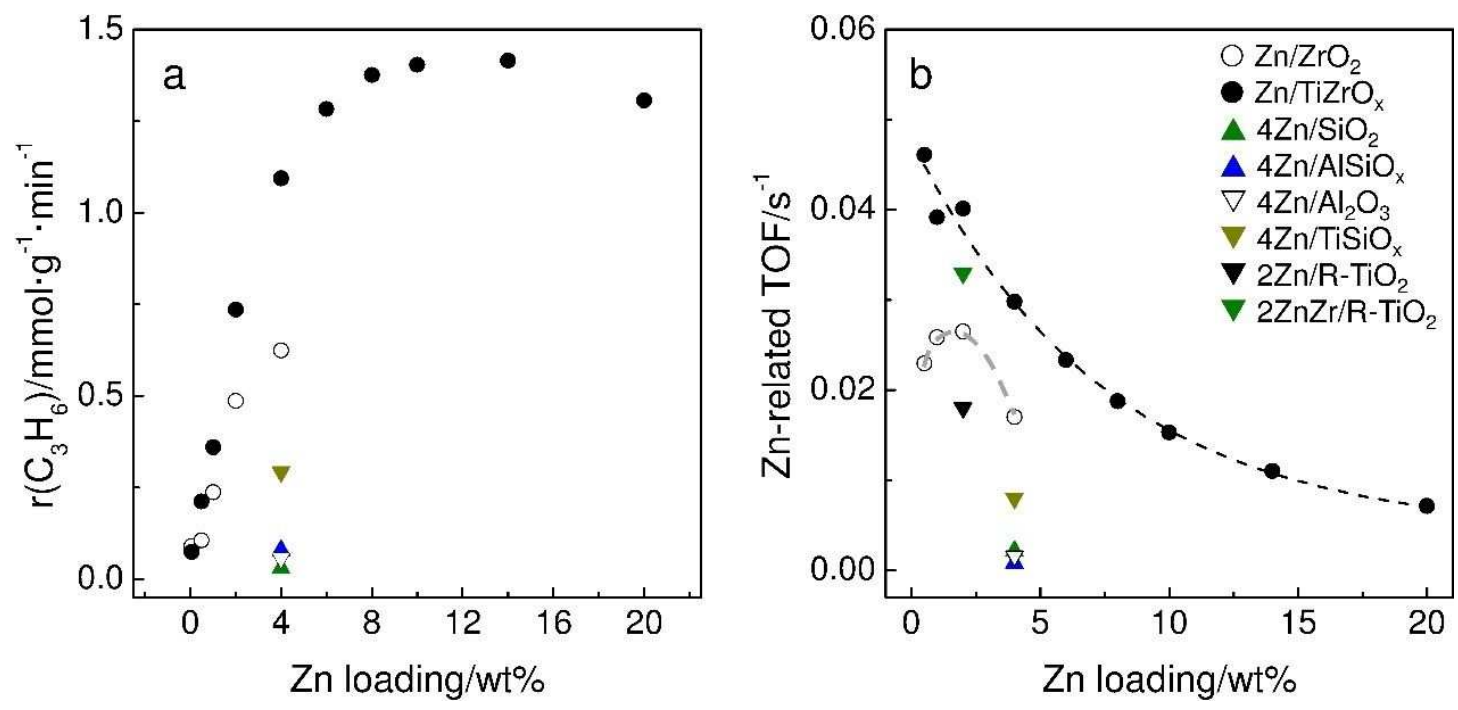

Figure 9. Propane formation rate (a) and $\mathrm{Zn}$-related TOF values (b) vs $\mathrm{Zn}$ loading. $\mathrm{Zn} / \mathrm{ZrO}_{2}(\mathrm{O}$ ), $\mathrm{Zn} / \mathrm{TiZrO}_{\mathrm{x}}(\bullet), 4 \mathrm{Zn} / \mathrm{SiO}_{2}(\boldsymbol{\Delta}), 4 \mathrm{Zn} / \mathrm{AlSiO}_{\mathrm{x}}(\boldsymbol{\Delta}), 4 \mathrm{Zn} / \mathrm{Al}_{2} \mathrm{O}_{3}(\nabla), 4 \mathrm{Zn} / \mathrm{TiSiO}_{\mathrm{x}}(\boldsymbol{\nabla}), 2 \mathrm{Zn} / \mathrm{R}-\mathrm{TiO}_{2}(\boldsymbol{\nabla})$, $2 \mathrm{ZnZr} / \mathrm{R}-\mathrm{TiO}_{2}(\boldsymbol{\nabla})$. Reaction conditions: $\mathrm{T}=550^{\circ} \mathrm{C}$, catalyst amount $=50 \mathrm{mg}, \mathrm{C}_{3} \mathrm{H}_{8}: \mathrm{N}_{2}=2: 3$, WHSV $\left(\mathrm{C}_{3} \mathrm{H}_{8}\right)=34.5 \mathrm{~h}^{-1}$, the catalysts were reduced in a flow of 50 vol\% $\mathrm{H}_{2}$ in $\mathrm{N}_{2}$ for $1 \mathrm{~h}$ at $550^{\circ} \mathrm{C}$ before the $\mathrm{PDH}$ reaction.

To check if $Z n$ sites are the only active species, we calculated an apparent TOF value related to total $Z n$ atoms. The obtained results are shown in Figure $9 b$. The TOF value for $\mathrm{Zn} / \mathrm{TiZrO}_{\mathrm{x}}$ decreases from 0.046 to $0.007 \mathrm{~s}^{-1}$ with rising $\mathrm{Zn}$ loading from 0.5 to $20 \mathrm{wt} \%$. The decrease is less pronounced when comparing samples exclusively possessing 
isolated tricoordinated $\mathrm{Zn}^{2+}$ sites, i.e. from 0.046 to $0.03 \mathrm{~s}^{-1}$ for the samples with $\mathrm{Zn}$ loading from 0.5 to $4 \mathrm{wt} . \%$. The TOF value for $\mathrm{Zn} / \mathrm{ZrO}_{2}$ with $0.5,1$ or $2 \mathrm{wt} \%$ are close to each other (between 0.023 and $0.026 \mathrm{~s}^{-1}$ ) but decreases to $0.017 \mathrm{~s}^{-1}$ with a further increase in the loading. The negative effect of $\mathrm{Zn}$ loading on the $\mathrm{Zn}$-related TOF value could be partially caused by aggregation of $\mathrm{ZnO}_{x}$ species as demonstrated by XRD. Taking into account the results of EXAFS analysis and catalytic tests in Figure 6a, we put forward that isolated tricoordinated $\mathrm{Zn}^{2+}$ should actively participate in propane dehydrogenation. It cannot be completely excluded that slightly oligomerized $\mathrm{ZnO}_{\mathrm{x}}$ also participate in this reaction. Moreover, when analyzing the TOF values determined for $\mathrm{Zn} / \mathrm{ZrO}_{2}$ and $\mathrm{Zn} / \mathrm{TiZrO}_{\mathrm{x}}$ materials, it becomes obvious that the latter system performs superior when comparing similarly loaded catalysts. Thus, the presence of $\mathrm{TiO}_{2}$ seems to be decisive for higher intrinsic activity of isolated tricoordinated $\mathrm{Zn}^{2+}$ sites. The below discussion supports this statement.

We now analyze the activity data obtained over the catalysts based on $\mathrm{Al}_{2} \mathrm{O}_{3}, \mathrm{SiO}_{2}$, $\mathrm{AlSiO}_{x}$ and $\mathrm{TiSiO}_{x}$ supports possessing $4 \mathrm{wt} \% \mathrm{Zn} . \mathrm{ZnO}$ species in these materials should also be highly dispersed as concluded from our XRD analysis (Figure S17). No sign for 
crystalline $\mathrm{ZnO}$ could be detected. The rate of propene formation and the $\mathrm{Zn}$-related TOF values are shown in Figure $9 \mathrm{a}$ and Figure $9 \mathrm{~b}$ respectively. The $4 \mathrm{Zn} / \mathrm{Al}_{2} \mathrm{O}_{3}, 4 \mathrm{Zn} / \mathrm{SiO}_{2}$ and $4 \mathrm{Zn} / \mathrm{AlSiO}_{\mathrm{x}}$ catalysts showed about 13 times lower rate in comparison with $4 \mathrm{Zn} / \mathrm{TiZrO}$. Importantly, the rate over $4 \mathrm{Zn} / \mathrm{TiSiO}{ }_{x}$ was significantly higher than over $4 \mathrm{Zn} / \mathrm{Al}_{2} \mathrm{O}_{3}$, $4 \mathrm{Zn} / \mathrm{SiO}_{2}$ and $4 \mathrm{Zn} / \mathrm{AlSiO}_{x}$, i.e. 0.29 versus $0.03-0.08 \mathrm{mmol} \cdot \mathrm{g}^{-1} \cdot \mathrm{min}^{-1}$. Thus, the presence of Ti appears to be important for the activity of $\mathrm{Zn}^{2+}$ sites. The above discussed effects of the rate and TOF of propene formation over different catalysts on $\mathrm{Zn}$ loading are also valid when this catalyst performance is plotted versus apparent $\mathrm{Zn}$ surface density (Figure S18).

To validate this hypothesis, we additionally prepared supported catalysts based on rutile $\mathrm{TiO}_{2}$ $\left(\mathrm{R}-\mathrm{TiO}_{2}\right) \cdot \mathrm{ZnO}(2 \mathrm{wt} \% \mathrm{Zn}$ loading $)$ and/or $\mathrm{MO}_{\mathrm{x}}(\mathrm{M}=\mathrm{La}, \mathrm{Y}, \mathrm{Zr}$ or Ce) were deposited on the surface of $\mathrm{R}-\mathrm{TiO}_{2}$. The rate of propene formation over these catalysts is shown in Figure S19. In comparison with $2 \mathrm{Zn} / \mathrm{R}-\mathrm{TiO}_{2}$, the rate of propene formation increased upon addition of $\mathrm{ZrO}_{2}$ but decreased when the oxide of $\mathrm{La}, \mathrm{Y}$ or Ce was added. Importantly, the $\mathrm{Zn}$-related TOF value determined for $2 \mathrm{ZnZr} / \mathrm{R}-\mathrm{TiO}_{2}$ is very close to that determined for $2 \mathrm{Zn} / \mathrm{TiZrO}_{x}$, i.e. 0.033 versus $0.04 \mathrm{~s}^{-1}$ (Figure 9b). Thus, interplay between $\mathrm{TiO}_{2}$ and $\mathrm{ZrO}_{2}$ with isolated tricoordinated $\mathrm{Zn}^{2+}$ species is highly relevant for the intrinsic activity of the latter. To check, if the oxidation state of $\mathrm{Zn}^{2+}, \mathrm{Zr}^{4+}$ and $\mathrm{Ti}^{4+}$ changes under reducing 
conditions, we carried out in-situ XANES tests with 20 vol\% $\mathrm{H}_{2}$ in $\mathrm{He}$ up to $600^{\circ} \mathrm{C}$ (Figure S20) and NAP-XPS measurements at $550^{\circ} \mathrm{C}$ using a $\mathrm{C}_{3} \mathrm{H}_{8}: \mathrm{H}_{2}: \mathrm{N}_{2}=8: 1: 11$ feed (Figure S21). No changes in the oxidation state could be determined by both techniques.

Rate-determining step. The temporal analysis of products (TAP) reactor operating at sub-millisecond contact time was applied for analyzing kinetically relevant step(s) in the course of the PDH reaction over $4 \mathrm{Zn} / \mathrm{ZrO}{ }_{2}$ and $4 \mathrm{Zn} / \mathrm{TiZrO}$. The catalysts were reduced in a similar way as for steady-state PDH tests (see Temporal Analysis of Products). In agreement with the latter test, propene and hydrogen were detected upon pulsing a $\mathrm{C}_{3} \mathrm{H}_{8} / \mathrm{Ar}=1 / 1$ at $550^{\circ} \mathrm{C}$. Figure $10 \mathrm{a}, \mathrm{b}$ shows the height-normalized responses of the alkane and the reaction products. The time scale in this figure is presented in a dimensionless form as suggested by Gleaves et al. ${ }^{36}$ The dimensionless time is defined as $t \cdot D_{i} / L^{2}$, where $t$ is the measured time, $D_{i}$ is the effective diffusion coefficient of each component, and $L$ is the reactor length. Such transformation is required for correct comparing the order of appearance of $\mathrm{C}_{3} \mathrm{H}_{n}$ ( $n=6$ or 8 ) and $\mathrm{H}_{2}$ strongly differing in their diffusion velocity due to diverse molecular weights. The diffusion coefficients of $\mathrm{C}_{3} \mathrm{H}_{8}, \mathrm{C}_{3} \mathrm{H}_{6}$, and $\mathrm{H}_{2}$ were calculated from that of Ar according to Ref. ${ }^{36}$. The diffusion length for $\mathrm{C}_{3} \mathrm{H}_{6}$ and $\mathrm{H}_{2}$ was 
set from the beginning of the catalyst layer to the reactor outlet, while the whole reactor length was taken into consideration for $\mathrm{C}_{3} \mathrm{H}_{8}$.
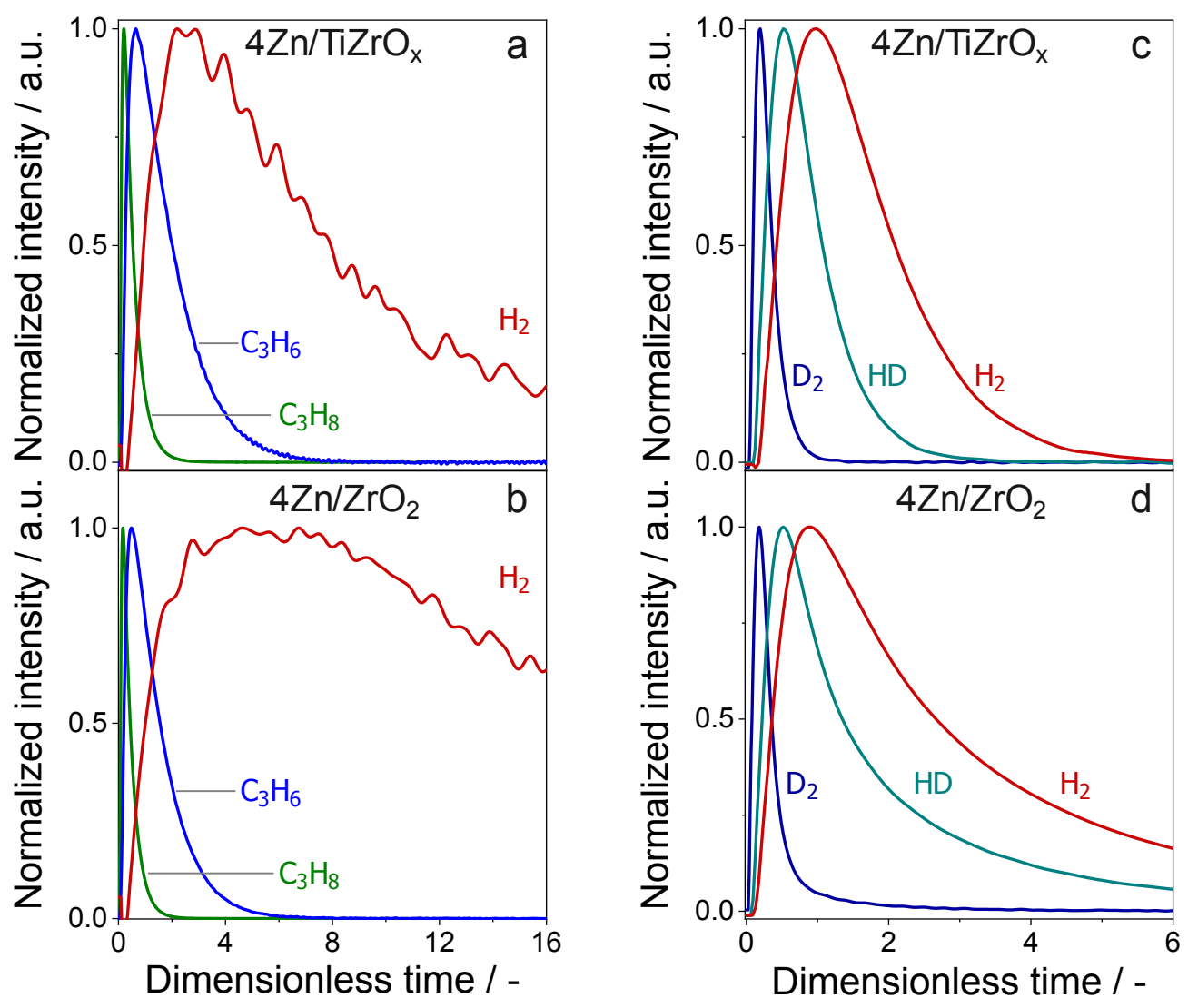

Figure 10. Normalized transient responses of $(a, b) \mathrm{C}_{3} \mathrm{H}_{8}$ (green), $\mathrm{C}_{3} \mathrm{H}_{6}$ (blue) and $\mathrm{H}_{2}$ (red) after pulsing of $\mathrm{C}_{3} \mathrm{H}_{8} / \mathrm{Ar}=1 / 1$ mixture and $(c, d) D_{2}, \mathrm{HD}$ and $\mathrm{H}_{2}$ after pulsing of a $D_{2} / A r=1 / 1$ mixture at $550^{\circ} \mathrm{C}$.

The responses of $\mathrm{C}_{3} \mathrm{H}_{6}$ and $\mathrm{H}_{2}$ appear after the response of $\mathrm{C}_{3} \mathrm{H}_{8}$ because these products are formed form the alkane. However, the kinetics of their formation is different 
as concluded from the position of maxima of the corresponding responses. The maximal formation rate of $\mathrm{H}_{2}$ was achieved when the rate of $\mathrm{C}_{3} \mathrm{H}_{6}$ formation already declined. Thus, we can conclude that the rate-limiting step in the course of $\mathrm{PDH}$ is $\mathrm{H}_{2}$ formation but not the cleavage of $\mathrm{C}-\mathrm{H}$ bonds in $\mathrm{C}_{3} \mathrm{H}_{8}$. It is also worth mentioning another important result shown in Figure 10a,b is the difference in the shape of $\mathrm{H}_{2}$ response obtained upon pulsing of $\mathrm{C}_{3} \mathrm{H}_{8}$ over $4 \mathrm{Zn} / \mathrm{ZrO} \mathrm{Z}_{2}$ and $4 \mathrm{Zn} / \mathrm{TiZrO}$. In comparison with the latter catalyst, the $\mathrm{H}_{2}$ response of $4 \mathrm{Zn} / \mathrm{ZrO}$ is broader, possesses longer tailing (non-zero concentration of $\mathrm{H}_{2}$ at long dimensionless time) and appears later. According to the theory of the TAP reactor, ${ }^{36} \mathrm{H}_{2}$ formation from $\mathrm{C}_{3} \mathrm{H}_{8}$ over $4 \mathrm{Zn} / \mathrm{ZrO}$ is slower in comparison with this process over $4 \mathrm{Zn} / \mathrm{TiZrO}_{\mathrm{x}}$. Thus, we can put forward that both the structure of $\mathrm{ZnO}_{\mathrm{x}}$ species and the presence of $\mathrm{Ti}$ in the support may be relevant for accelerating $\mathrm{H}_{2}$ formation.

We also investigated hydrogen activation over these two catalysts. To this end, a $D_{2} / A r=1 / 1$ mixture was pulsed. $H D$ and $H_{2}$ were observed at the reactor outlet (Figure $10 \mathrm{c}, \mathrm{d})$. The presence of these products means that $\mathrm{D}_{2}$ reacted with surface $\mathrm{H}$-containing species, probably, $\mathrm{OH}$ groups. As $\mathrm{H}_{2}$ appears after $\mathrm{HD}$ its formation can be ascribed to a consecutive exchange reaction of the latter. Although the sequence of $\mathrm{HD}$ and $\mathrm{H}_{2}$ 
formation is same upon $\mathrm{D}_{2}$ isotopic exchange over $4 \mathrm{Zn} / \mathrm{ZrO}_{2}$ and $4 \mathrm{Zn} / \mathrm{TiZrO}$, the corresponding responses obtained over these catalysts strongly differ in their shape. Similar to the $\mathrm{H}_{2}$ response in $\mathrm{C}_{3} \mathrm{H}_{8}$ pulse experiments (Figure 10a,b), the responses of $\mathrm{HD}$ and $\mathrm{H}_{2}$ obtained after pulsing of $\mathrm{D}_{2} / \mathrm{Ar}$ over $4 \mathrm{Zn} / \mathrm{ZrO}_{2}$ (Figure $10 \mathrm{c}, \mathrm{d}$ ) are significantly broader and possess longer tailing than those obtained over $4 \mathrm{Zn} / \mathrm{TiZrO}$. The differences are due to faster kinetics of hydrogen desorption/formation over the latter catalyst.

Coke Formation and Removal. It is well known that coke formation is one of the main reasons causing deactivation of catalysts used for the $\mathrm{PDH}$ reaction. ${ }^{62,63}$ This should also be valid for our catalysts as they lose their activity with time on propane stream (Figure 7). To derive mechanistic insights into the effect of metal oxide promoter for $\mathrm{ZrO}_{2}$ in $4 \mathrm{Zn} / \mathrm{MZrO}_{\mathrm{x}}$ and/or the kind of supported $\mathrm{ZnO}_{\mathrm{x}}$ species on coke formation, we applied exsitu Raman and operando UV-vis spectroscopy for catalyst characterization. The Raman spectra of selected spent (after $1 \mathrm{~h}$ propane on-stream shown in Figure $7 \mathrm{a}$ ) catalysts are shown in Figure S22. According to Weckhuysen et al. ${ }^{64}$, two distinct bands identified at around 1595 and $1345 \mathrm{~cm}^{-1}$ are characteristic for graphite $(G)$ and disordered graphite (D) coke species, respectively. The calculated average ratio of $G$ to $D$ for these three 
catalysts from ten Raman spectra recorded at different catalyst places is almost the same suggesting the structure of coke species is similar.

The operando UV-vis spectra expressed as $F\left(R_{\text {rel }}\right)$ (see Eq. 4) after different times on propane stream are shown in Figure 11. Although for all catalysts, $F\left(R_{\text {rel }}\right)$ increased practically across the whole wavelength range due to the coke formation, there are some significant differences in the shape of the spectra and the absorption range. For the $4 \mathrm{Zn} / \mathrm{ZrO}_{2}, 4 \mathrm{Zn} / \mathrm{LaZrO}_{\mathrm{x}}$ and $4 \mathrm{Zn} / \mathrm{YZrO}_{\mathrm{x}}$ catalysts, $\mathrm{F}\left(\mathrm{R}_{\mathrm{rel}}\right)$ from about $385 \mathrm{~nm}$ increased with rising time on propane stream. In comparison with these catalysts, no significant changes in $\mathrm{F}\left(\mathrm{R}_{\text {rel }}\right)$ below $460 \mathrm{~nm}$ was observed for $4 \mathrm{Zn} / \mathrm{CeZrO}$. For $4 \mathrm{Zn} / \mathrm{TiZrO}$, the reactioninduced changes in the absorption were observed from about $330 \mathrm{~nm}$.

To get an insight into the nature of coke species, the UV-vis spectra after $60 \mathrm{~min}$ propane on-stream were deconvoluted by Gaussian functions. The fitting results are shown in Figure S23. Bands at about 465, 525, 600 and $815 \mathrm{~nm}$ can be identified for $4 \mathrm{Zn} / \mathrm{ZrO}{ }_{2}, 4 \mathrm{Zn} / \mathrm{LaZrO}_{\mathrm{x}}$ and $4 \mathrm{Zn} / \mathrm{YZrO}_{\mathrm{x}}$. For $4 \mathrm{Zn} / \mathrm{TiZrO}$, there are bands located at about 440, 543, 718 and $903 \mathrm{~nm}$. Only two absorption bands at 633 and $823 \mathrm{~nm}$ were identified for $4 \mathrm{Zn} / \mathrm{CeZrO}_{\mathrm{x}}$. Coke species with higher polymerization degree absorb at higher 
wavelength in comparison with their less polymerized counterparts. ${ }^{65}$ On this basis, we could roughly divide the coke species into three kinds: low-condensed (below $500 \mathrm{~nm}$ ), medium-condensed $(500-800 \mathrm{~nm})$ and highly condensed aromatics (above $800 \mathrm{~nm}$ ). Obviously, all these species were formed on the surface of $4 \mathrm{Zn} / \mathrm{ZrO}_{2}, 4 \mathrm{Zn} / \mathrm{LaZrO}$ and $4 \mathrm{Zn} / \mathrm{YZrO}_{\mathrm{x}}$. Based on the deconvoluted UV-Vis spectra in Figure S23, one can assume that the dominant coke species should be highly condensed aromatics. Such species were also mainly formed over $4 \mathrm{Zn} / \mathrm{CeZrO}_{\mathrm{x}}$, while no low-condensed aromatics were found. In comparison with these four catalysts, medium- and low-condensed aromatics are the main coke species on the surface of $4 \mathrm{Zn} / \mathrm{TiZrO}_{\mathrm{x}}$. Thus, the kind of $\mathrm{ZnO}_{\mathrm{x}}$ species in $\mathrm{Zn} / \mathrm{MZrO}_{\mathrm{x}}$ appears to determine the type of coke species formed under PDH conditions. This hypothesis is supported by the discussion at the end of this chapter under consideration of additional experimental data. 

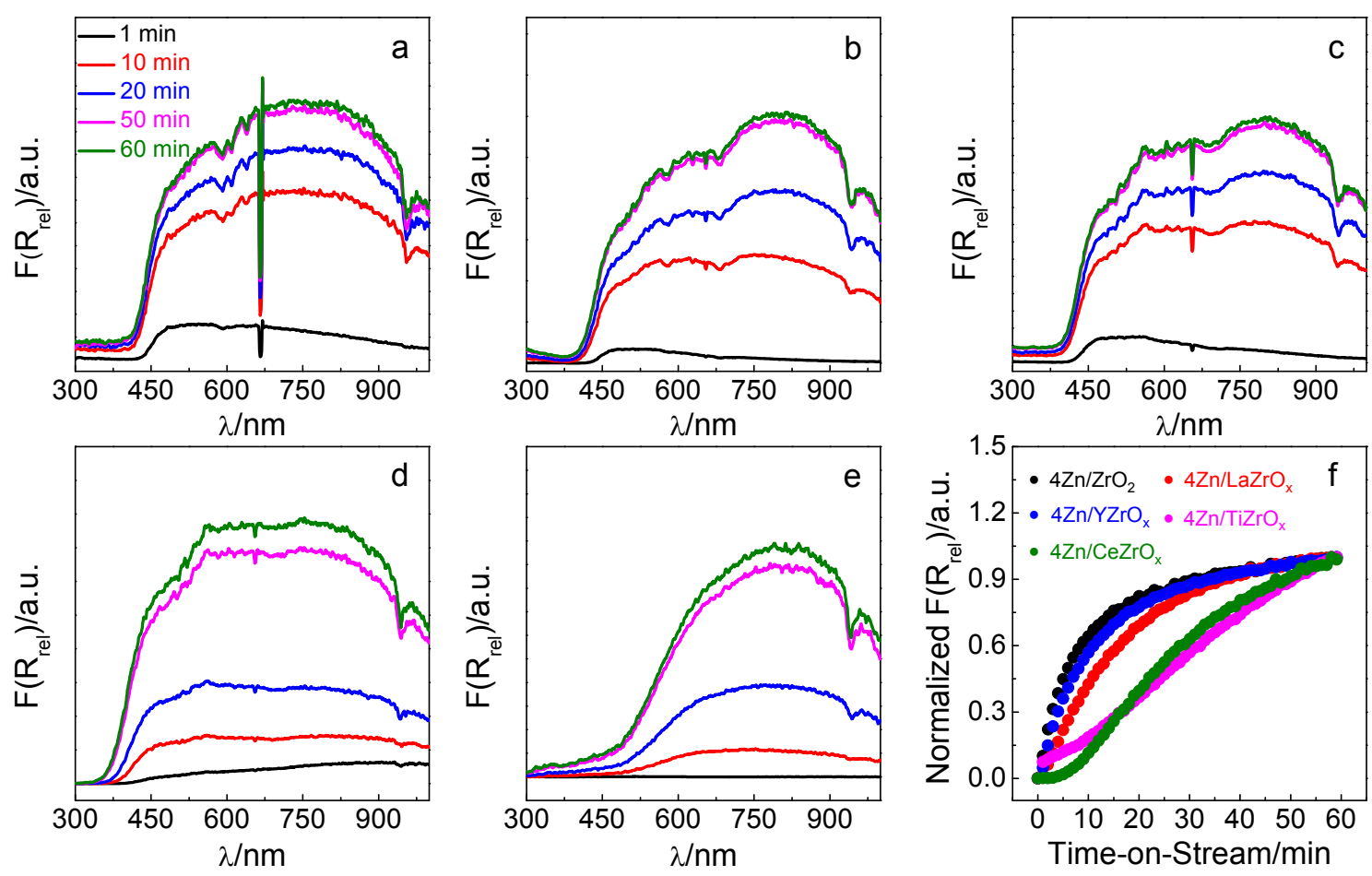

Figure 11. Operando UV-vis spectra of reduced (a) $4 \mathrm{Zn} / \mathrm{ZrO}_{2}$, (b) $4 \mathrm{Zn} / \mathrm{LaZrO}_{\mathrm{x}}$, (c) $4 \mathrm{Zn} / \mathrm{YZrO}_{\mathrm{x}}$, (d) $4 \mathrm{Zn} / \mathrm{TiZrO}_{\mathrm{x}}$, (e) $4 \mathrm{Zn} / \mathrm{CeZrO}_{\mathrm{x}}$ and (f) height-normalized $\mathrm{F}\left(\mathrm{R}_{\mathrm{rel}}\right)$ at $800 \mathrm{~nm}$ after different times on propane stream.

Kinetic insights into coke formation and oxidation were derived from analyzing temporal evolution of $F\left(R_{\text {rel }}\right)$ at $800 \mathrm{~nm}$ during the $\mathrm{PDH}$ reaction (Figure 11f) and catalyst oxidative regeneration (Figure $S 24)$ respectively. $F\left(R_{\text {rel }}\right)$ at $800 \mathrm{~nm}$ could be an indicator of highly polymerized aromatics. ${ }^{66}$ The profiles after PDH were normalized by their highest values achieved at the end of the test for an easier comparison of their slopes. Unfortunately, 
their absolute intensity is not a direct measure of the amount of coke formed. The catalysts can be ordered in terms of their activity for coke formation (slope of the $F\left(R_{\text {rel }}\right)$ time dependence in Figure 11f) as follows: $4 \mathrm{Zn} / \mathrm{ZrO}_{2}>4 \mathrm{ZnYZrO}{ }_{\mathrm{x}}>4 \mathrm{Zn} / \mathrm{LaZrO}_{\mathrm{x}}>$ $4 \mathrm{Zn} / \mathrm{CeZrO}_{x}>4 \mathrm{Zn} / \mathrm{TiZrO}{ }_{x}$. For all the catalysts, the rate of coke removal is significantly higher in comparison with the rate of coke formation as concluded from the evolution profiles of $F\left(R_{\text {rel }}\right)$ recorded upon catalyst reoxidation (Figure $\left.S 24\right)$. $F\left(R_{\text {rel }}\right)$ of spent catalyst reached the value characteristic for fresh catalyst after only 5 min on air stream.

To determine the amount of coke and the temperature required to oxidize this undesired reaction product, TPO tests were performed with spent catalysts after reacting with $\mathrm{C}_{3} \mathrm{H}_{8}$ (40 vol\% $\mathrm{C}_{3} \mathrm{H}_{8}$ and 5 vol\% $\mathrm{H}_{2}$ in $\mathrm{N}_{2}$ ) at $550^{\circ} \mathrm{C}$ for $1 \mathrm{~h}$ (catalytic data are shown in Figure 7a). TPO profiles in the form of $\mathrm{CO}_{2} / \mathrm{Ar} \mathrm{MS}$ signal are shown in Figure 12a. Based on the shape of $\mathrm{CO}_{2}$ profiles and $\mathrm{T}_{\max }-\mathrm{CO}_{2}$ values (temperature of maximal $\mathrm{CO}_{2}$ production), the catalysts can be divided into three groups: (i) $4 \mathrm{Zn} / \mathrm{CeZrO}_{x}$, (ii) $4 \mathrm{Zn} / \mathrm{ZrO}{ }_{2}, 4 \mathrm{Zn} / \mathrm{LaZrO}_{x}$ and $4 \mathrm{Zn} / \mathrm{YZrO}_{\mathrm{x}}$ and (iii) $4 \mathrm{Zn} / \mathrm{TiZrO}_{\mathrm{x}}$. Actually, the catalysts can be assigned to the same groups when comparing the operando UV-vis spectra in Figure 11. 
The lowest $\mathrm{T}_{\max }-\mathrm{CO}_{2}$ value of $310^{\circ} \mathrm{C}$ was determined for $4 \mathrm{Zn} / \mathrm{CeZrO}$, while $4 \mathrm{Zn} / \mathrm{TiZrO}$ x required the highest temperature (above $430^{\circ} \mathrm{C}$ ) to oxidize coke. In comparison with these two catalysts, two maxima of $\mathrm{CO}_{2}$ evaluation at around 310 and $380^{\circ} \mathrm{C}$ were determined for the catalysts from group (ii). When comparing the $\mathrm{T}_{\max }-\mathrm{CO}_{2}$ values with catalyst reducibility determined through CO-TPR tests (Table 2), one may conclude that the latter catalyst property is important for oxidative removal of coke.
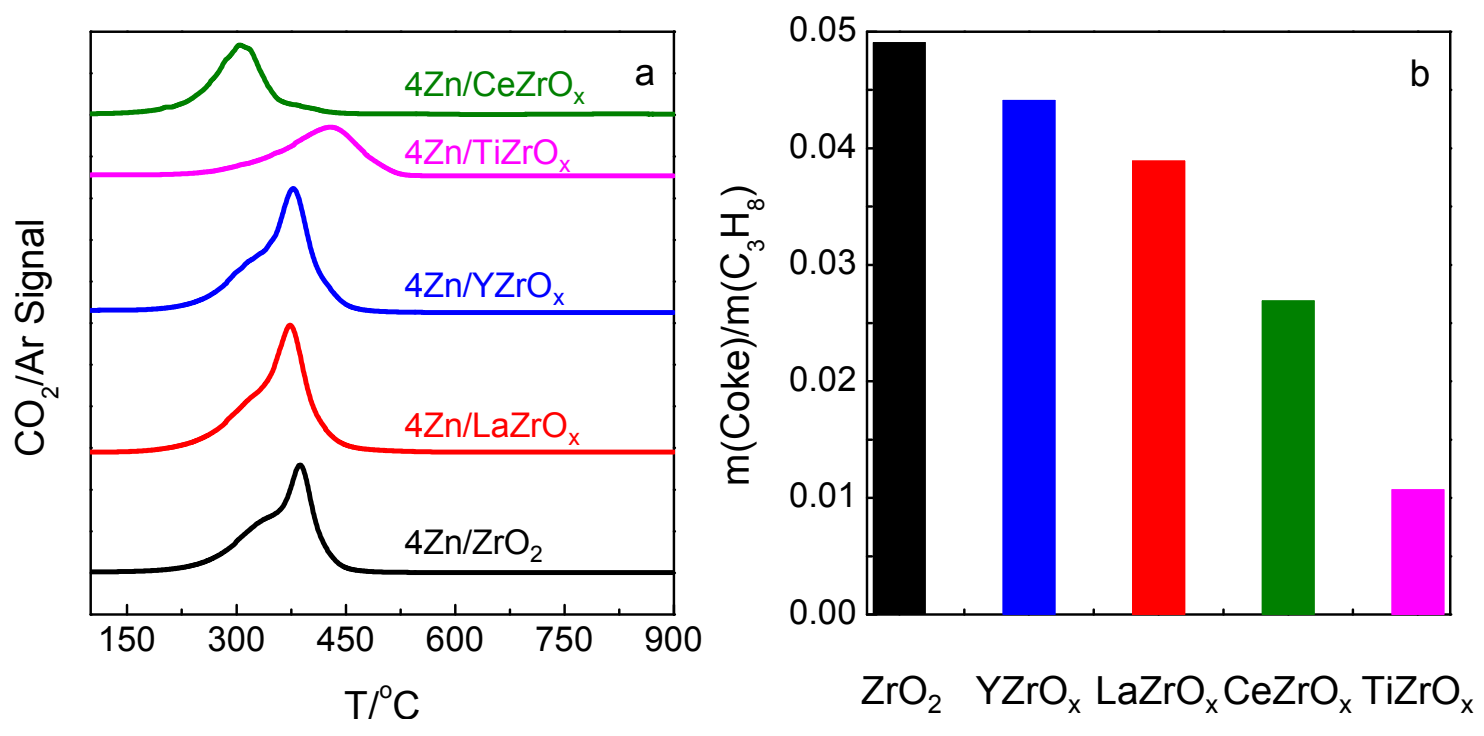

Figure 12. (a) TPO profiles of samples (oxidized) after exposing to propane for $1 \mathrm{~h}$ and (b) the ratio of the amount of coke formed to that of converted $\mathrm{C}_{3} \mathrm{H}_{8}$.

The catalysts were also compared for their ability to form coke in a quantitative manner.

To this end, we integrated the $\mathrm{CO}_{2}$ profiles obtained in TPO of spent catalysts. The 
amount of released $\mathrm{CO}_{2}$ corresponds to the amount of coke $(\mathrm{m}($ coke $))$ formed in the PDH reaction. When comparing catalysts in terms of coke formation, it is important to consider the amount of propane converted, because coke is mainly formed from propene and to a minor extent directly from propane. Thus, we used the ratio of the amount of $\mathrm{CO}_{2}$ to that of converted $\mathrm{C}_{3} \mathrm{H}_{8}$. The total amount of consumed propane $\left(\mathrm{m}\left(\mathrm{C}_{3} \mathrm{H}_{8}\right)\right)$ was calculated using the conversion profiles from Figure $7 \mathrm{a}$. The $\left(\mathrm{m}(\mathrm{coke}) / \mathrm{m}\left(\mathrm{C}_{3} \mathrm{H}_{8}\right)\right)$ ratio also stands for integral coke selectivity. This ratio is shown in Figure 12b. The highest value was determined for $4 \mathrm{Zn} / \mathrm{ZrO}_{2}$ and decreased in the following order: $4 \mathrm{Zn} / \mathrm{ZrO} \mathrm{O}_{2}>4 \mathrm{Zn} / \mathrm{YZrO}_{\mathrm{x}}>$ $4 \mathrm{Zn} / \mathrm{LaZrO}_{\mathrm{x}}>4 \mathrm{Zn} / \mathrm{CeZrO}_{\mathrm{x}}>4 \mathrm{Zn} / \mathrm{TiZrO}_{\mathrm{x}}$. A similar order was also obtained for the $\mathrm{S}_{\mathrm{BET}^{-}}$ related amount of coke formed with $1 \mathrm{~h}$ on propane stream (Table S4).

What is the reason behind the different catalyst behavior with respect to coke formation? Catalyst acidity is often reported to be one of the important parameters affecting coke formation in the PDH reaction. ${ }^{67,68}$. To check this hypothesis for our materials, we tried to correlate the mass-based selectivity to coke with the concentration of acidic sites determined from $\mathrm{NH}_{3}$-TPD (Table 2). A correlation was established for the $4 \mathrm{Zn} / \mathrm{ZrO}{ }_{2}, 4 \mathrm{Zn} / \mathrm{YZrO}_{\mathrm{x}}, 4 \mathrm{Zn} / \mathrm{LaZrO}_{\mathrm{x}}$, and $4 \mathrm{Zn} / \mathrm{CeZrO}_{\mathrm{x}}$ catalysts (Figure 13a). However, the 
$4 \mathrm{Zn} / \mathrm{TiZrO}_{\mathrm{x}}$ catalyst possessing the highest concentration of acidic sites did not fit to this correlation. In fact, it showed the lowest selectivity to coke. Thus, catalyst acidity as determined by us should not be the main property affecting coke formation. However, when the selectivity to coke is plotted versus the concentration of basic sites determined from $\mathrm{CO}_{2}$-TPD (Table 2), one can see a trend holding for all catalysts (Figure 13b). The selectivity seems to positively depend on the basicity.
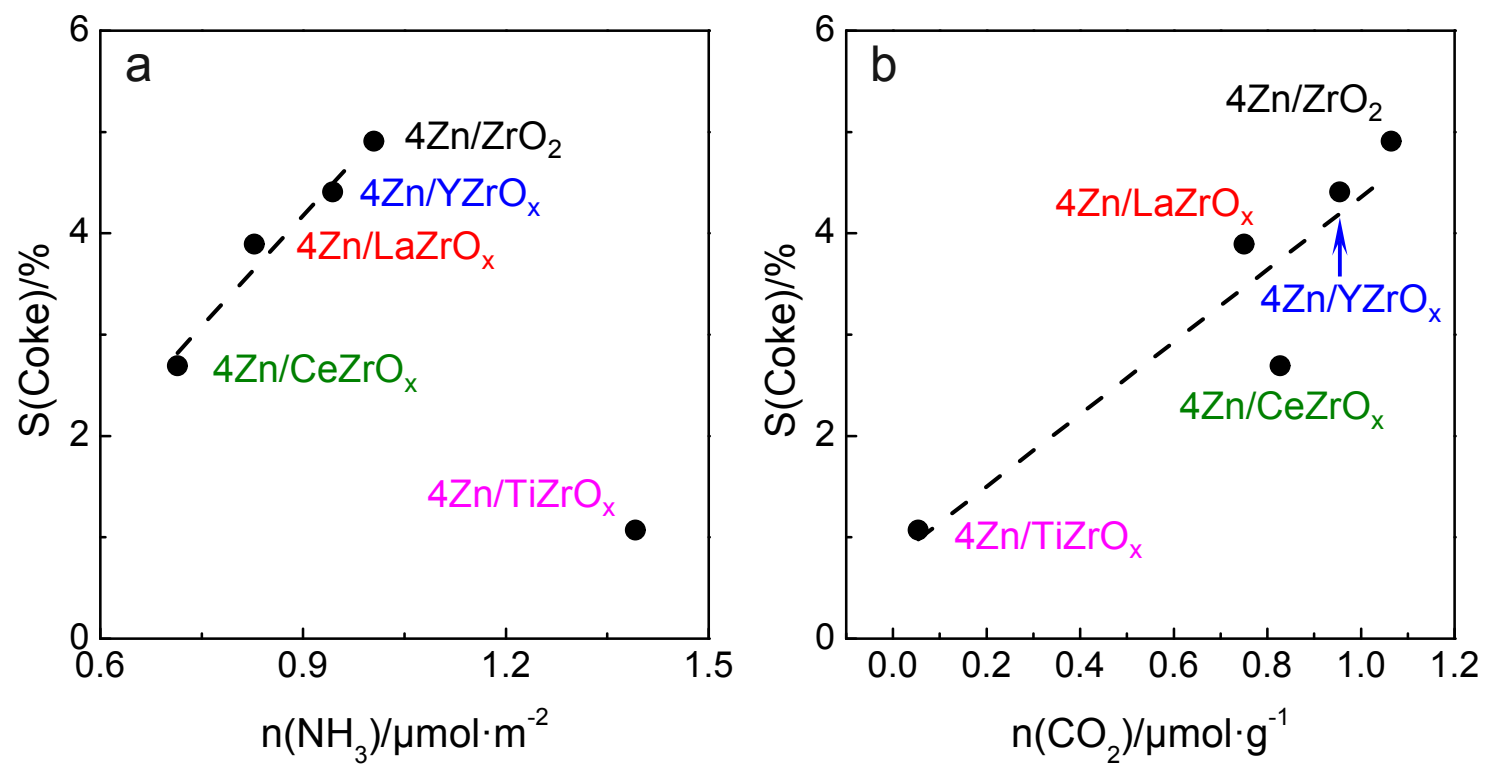

Figure 13. Effects of (a) overall catalyst acidity $\left(n\left(\mathrm{NH}_{3}\right)\right)$ or $(\mathrm{b})$ basicity $\left(\mathrm{n}\left(\mathrm{CO}_{2}\right)\right)$ on massbased selectivity to coke (S(coke)).

The effect of catalyst basicity on the selectivity to coke can be explained as follows. As seen in Table 2, the number of basic sites in general increased after depositing $\mathrm{ZnO}_{\mathrm{x}}$ due 
to basic nature of this metal oxide. The presence of nanosized $\mathrm{ZnO}$ clusters can be a reason for the high basicity of the $4 \mathrm{Zn} / \mathrm{ZrO}{ }_{2}, 4 \mathrm{Zn} / \mathrm{YZrO}_{\mathrm{x}}, 4 \mathrm{Zn} / \mathrm{LaZrO} \mathrm{r}_{\mathrm{x}}$ and $4 \mathrm{Zn} / \mathrm{CeZrO}$ catalysts (Table 2). $4 \mathrm{Zn} / \mathrm{TiZrO}_{\mathrm{x}}$ possessing exclusively isolated tricoordinated $\mathrm{Zn}^{2+}$ species does not practically possess basic sites. Under these considerations, we suggest that the kind of supported $\mathrm{ZnO}_{\mathrm{x}}$ species is a decisive factor for coke formation. Such species also participates in propane dehydrogenation. Based on our previous study of the $\mathrm{PDH}$ reaction over $\mathrm{VO}_{\mathrm{x}}$-based catalysts, ${ }^{69}$ formation of coke is favored at high density of adsorbed propene species. Such situation is easily realized for nanosized $\mathrm{ZnO}_{\mathrm{x}}$ species but hindered for their isolated counterparts. This statement is indirectly supported by the results of operando UV-vis tests (Figure S23). Highly polymerized aromatic coke species dominate on the surface of catalysts with nano sized $\mathrm{ZnO}_{\mathrm{x}}$ species. Contrarily, less oligomerized coke species were formed on isolated tricoordinated $\mathrm{Zn}^{2+}$ species $\left(4 \mathrm{Zn} / \mathrm{TiZrO}_{\mathrm{x}}\right)$.

\section{CONCLUSIONS}

In conclusion, we have demonstrated that simple deposition of $\mathrm{ZnO}$ on $\mathrm{ZrO}_{2}$-based supports is an efficient method for preparation of highly active and selective catalysts for 
the non-oxidative propane dehydrogenation to propene. In comparison with the state-ofthe-art $\mathrm{ZrO}_{2}$-based catalysts, the selectivity to propene could be improved when using $\mathrm{TiZrO}_{\mathrm{x}}$ support for $\mathrm{ZnO}$ species. The activity of such catalysts was also superior to that of a commercial-like $\mathrm{K}-\mathrm{CrO}_{x} / \mathrm{Al}_{2} \mathrm{O}_{3}$, while the selectivity to propene was close, i.e. about $96 \%$ at a propane conversion of $30 \%$.

On the basis of the results of catalytic tests and Zn K-edge Extended Xray Absorption Fine Structure analysis, isolated $\mathrm{Zn}^{2+}$ cations anchored on $\mathrm{ZrO}_{2}$ were suggested to actively participate in the target reaction. They reveal low ability towards coke formation and accordingly low deactivation. In contrast to crystalline $\mathrm{ZrO}_{2}$, the usage of X-ray amorphous $\mathrm{ZrO}_{2}$ is of advantage for homogeneous distribution of $\mathrm{Zn}^{2+}$ on the surface $\mathrm{ZrO}_{2}$. The kind of metal oxide promoter for crystalline $\mathrm{ZrO}_{2}$ also affects the distribution. The obtained catalytic data strongly suggest that there is a synergy effect between $\mathrm{Zn}^{2+}$, $\mathrm{ZrO}_{2}$ and $\mathrm{TiO}_{2}$ in terms of the intrinsic activity of the active sites. Further improvements are expected when the distribution of $\mathrm{Ti}^{4+}$ within $\mathrm{ZrO}_{2}$ and the size of $\mathrm{ZrO}_{2}$ crystallites can be tuned as these parameters are relevant for the activity of $\mathrm{Zn}^{2+}$ cations to form/desorb 


\author{
hydrogen. This reaction pathway was established to limit propene formation in the course \\ of propane dehydrogenation to propene.

\section{ASSOCIATED CONTENT}

\title{
Supporting Information.
}

The following files are available free of charge.

\author{
Additional table summary of $\mathrm{NH}_{3}$-TPD and $\mathrm{CO}_{2}$-TPD results, TPO results, HRTEM \\ images, EDX mapping, XANES spectra, XP spectra, NAP-XP spectra, $\mathrm{NH}_{3}$-TPD profiles, \\ $\mathrm{CO}_{2}$-TPD profiles, CO-TPR profiles, activation energy $\left(E_{\mathrm{a}}\right)$, XRD patterns, Raman \\ spectra, in-situ UV-vis spectra and activity data for $2 \mathrm{Zn}(\mathrm{M}) / \mathrm{R}-\mathrm{TiO}_{2}$ catalysts (PDF)
}

\author{
Corresponding Authors \\ *E-mail: Evgenii.Kondratenko@catalysis.de (primary corresponding author) \\ *E-mail: jianggy@cup.edu.cn
}

\section{Notes}


The authors declare no competing financial interest.

\section{ACKNOWLEDGMENT}

The authors thank Dr. Reinhard Eckelt for $\mathrm{N}_{2}$ adsorption and desorption analysis.

Financial support by Deutsche Forschungsgemeinschaft (KO 2261/8-1 and JI 210/1-1),

National Natural Science Foundation of China (Grants 21961132026, 21878331, 91645108), Science Foundation of China University of Petroleum, Beijing (C201604) and the State of Mecklenburg-Vorpommern are gratefully acknowledged. Shanlei Han acknowledges the financial support from the China Scholarship Council. We thank the Synchrotron Radiation Source at KIT (Karlsruhe) for providing beamtime for this study at the Cat-Act beamline and Dr. Tim Pruessmann and Dr. Anna Zimina for their help during measurements.

\section{REFERENCES}

(1) Nawaz, Z. Light Alkane Dehydrogenation to Light Olefin Technologies: A Comprehensive Review. Rev. Chem. Eng. 2015, 31, 413-436. 
(2) Gao, X.-Q.; Lu, W.-D.; Hu, S.-Z.; Li, W.-C.; Lu, A.-H. Rod-shaped Porous AluminaSupported $\mathrm{Cr}_{2} \mathrm{O}_{3}$ Catalyst with Low Acidity for Propane Dehydrogenation. Chin. J. Catal. 2019, 40, 184-191.

(3) Blay, V.; Epelde, E.; Miravalles, R.; Perea, L. A. Converting Olefins to Propene: Ethene to Propene and Olefin Cracking. Catal. Rev. 2018, 60, 278-335.

(4) Ridha, T.; Li, Y.; Gençer, E.; Siirola, J.; Miller, J.; Ribeiro, F.; Agrawal, R. Valorization of Shale Gas Condensate to Liquid Hydrocarbons through Catalytic Dehydrogenation and Oligomerization. Processes. 2018, 6, 139-159.

(5) Wu, T.; Liu, G.; Zeng, L.; Sun, G.; Chen, S.; Mu, R.; Agbotse Gbonfoun, S.; Zhao, Z.-J.; Gong, J. Structure and Catalytic Consequence of Mg-Modified $\mathrm{VO}_{x} / \mathrm{Al}_{2} \mathrm{O}_{3}$ Catalysts for Propane Dehydrogenation. A/ChE J. 2017, 63, 4911-4919.

(6) Sattler, J. J. H. B.; Gonzalez-Jimenez, I. D.; Luo, L.; Stears, B. A.; Malek, A.; Barton, D. G.; Kilos, B. A.; Kaminsky, M. P.; Verhoeven, T. W.; Koers, E. J.; Baldus, M.;

Weckhuysen, B. M. Platinum-Promoted $\mathrm{Ga} / \mathrm{Al}_{2} \mathrm{O}_{3}$ as Highly Active, Selective, and Stable Catalyst for the Dehydrogenation of Propane. Angew. Chem., Int. Ed. 2014, 53, 9251-6. 
(7) Sokolov, S.; Stoyanova, M.; Rodemerck, U.; Linke, D.; Kondratenko, E. V. Effect of Support on Selectivity and On-Stream Stability of Surface $\mathrm{VO}_{\mathrm{x}}$ Species in Non-Oxidative Propane Dehydrogenation. Catal. Sci. Technol. 2014, 4, 1323-1332.

(8) Ovsitser, O.; Schomaecker, R.; Kondratenko, E. V.; Wolfram, T.; Trunschke, A. Highly Selective and Stable Propane Dehydrogenation to Propene over Dispersed $\mathrm{VO}_{\mathrm{x}^{-}}$ Species under Oxygen-Free and Oxygen-Lean Conditions. Catal. Today. 2012, 192, 1619.

(9) Rodemerck, U.; Stoyanova, M.; Kondratenko, E. V.; Linke, D. Influence of the Kind of $\mathrm{VO}_{\mathrm{x}}$ Structures in $\mathrm{VO}_{\mathrm{x}} / \mathrm{MCM}-41$ on Activity, Selectivity and Stability in Dehydrogenation of Propane and Isobutane. J. Catal. 2017, 352, 256-263.

(10) Sokolov, S.; Stoyanova, M.; Rodemerck, U.; Linke, D.; Kondratenko, E. V. Comparative Study of Propane Dehydrogenation over V-, Cr-, and Pt-Based Catalysts: Time On-Stream Behavior and Origins of Deactivation. J. Catal. 2012, 293, 67-75. 
(11) Wang, G.; Zhang, H.; Wang, H.; Zhu, Q.; Li, C.; Shan, H. The Role of Metallic Sn

Species in Catalytic Dehydrogenation of Propane: Active Component Rather than Only Promoter. J. Catal. 2016, 344, 606-608.

(12) Wang, G.; Zhang, H.; Zhu, Q.; Zhu, X.; Li, X.; Wang, H.; Li, C.; Shan, H. SnContaining Hexagonal Mesoporous Silica (HMS) for Catalytic Dehydrogenation of Propane: An Efficient Strategy to Enhance Stability. J. Catal. 2017, 351, 90-94.

(13) Hu, P.; Lang, W.-Z.; Yan, X.; Chu, L.-F.; Guo, Y.-J. Influence of Gelation and Calcination Temperature on the Structure-Performance of Porous $\mathrm{VO}_{\mathrm{x}}-\mathrm{SiO}_{2}$ Solids in Non-Oxidative Propane Dehydrogenation. J. Catal. 2018, 358, 108-117.

(14) Rodemerck, U.; Sokolov, S.; Stoyanova, M.; Bentrup, U.; Linke, D.; Kondratenko, E. V. Influence of Support and Kind of $\mathrm{VO}_{\mathrm{x}}$ Species on Isobutene Selectivity and Coke Deposition in Non-Oxidative Dehydrogenation of Isobutane. J. Catal. 2016, 338, 174-183.

(15) Liu, G.; Zeng, L.; Zhao, Z.-J.; Tian, H.; Wu, T.; Gong, J. Platinum-Modified $\mathrm{ZnO} / \mathrm{Al}_{2} \mathrm{O}_{3}$ for Propane Dehydrogenation: Minimized Platinum Usage and Improved Catalytic Stability. ACS Catal. 2016, 6, 2158-2162. 
(16) Schweitzer, N. M.; Hu, B.; Das, U.; Kim, H.; Greeley, J.; Curtiss, L. A.; Stair, P. C.;

Miller, J. T.; Hock, A. S. Propylene Hydrogenation and Propane Dehydrogenation by a Single-Site $\mathrm{Zn}^{2+}$ on Silica Catalyst. ACS Catal. 2014, 4, 1091-1098.

(17) Chen, C.; Hu, Z.; Ren, J.; Zhang, S.; Wang, Z.; Yuan, Z.-Y. ZnO Nanoclusters Supported on Dealuminated Zeolite $\beta$ as a Novel Catalyst for Direct Dehydrogenation of Propane to Propylene. ChemCatChem. 2019, 11, 868-877.

(18) Zhao, D.; Li, Y.; Han, S.; Zhang, Y.; Jiang, G.; Wang, Y.; Guo, K.; Zhao, Z.; Xu, C.; Li, R.; Yu, C.; Zhang, J.; Ge, B.; Kondratenko, E. V. ZnO Nanoparticles Encapsulated in Nitrogen-Doped Carbon Material and Silicalite-1 Composites for Efficient Propane Dehydrogenation. iScience. 2019, 13, 269-276.

(19) Sun, Y.-n.; Gao, C.; Tao, L.; Wang, G.; Han, D.; Li, C.; Shan, H. Zn-Nb-O Catalysts for Propylene Production via Catalytic Dehydrogenation of Propane. Catal. Commun. 2014, 50, 73-77.

(20) Otroshchenko, T.; Sokolov, S.; Stoyanova, M.; Kondratenko, V. A.; Rodemerck, U.; Linke, D.; Kondratenko, E. V. $\mathrm{ZrO}_{2}$-Based Alternatives to Conventional Propane 
Dehydrogenation Catalysts: Active Sites, Design, and Performance. Angew. Chem., Int.

Ed. 2015, 54, 15880-15883.

(21) Otroshchenko, T. P.; Kondratenko, V. A.; Rodemerck, U.; Linke, D.; Kondratenko,

E. V. Non-Oxidative Dehydrogenation of Propane, n-butane, and Isobutane over Bulk

$\mathrm{ZrO}_{2}$-Based Catalysts: Effect of Dopant on the Active Site and Pathways of Product

Formation. Catal. Sci. Technol. 2017, 7, 4499-4510.

(22) Otroshchenko, T.; Kondratenko, V. A.; Rodemerck, U.; Linke, D.; Kondratenko, E.

V. $\mathrm{ZrO}_{2}$-Based Unconventional Catalysts for Non-Oxidative Propane Dehydrogenation:

Factors Determining Catalytic Activity. J. Catal. 2017, 348, 282-290.

(23) Zhang, Y.; Zhao, Y.; Otroshchenko, T.; Han, S.; Lund, H.; Rodemerck, U.; Linke, D.; Jiao, H.; Jiang, G.; Kondratenko, E. V. The Effect of Phase Composition and Crystallite Size on Activity and Selectivity of $\mathrm{ZrO}_{2}$ in Non-Oxidative Propane Dehydrogenation. J.

Catal. 2019, 371, 313-324. 
(24) Zhang, Y.; Zhao, Y.; Otroshchenko, T.; Lund, H.; Pohl, M. M.; Rodemerck, U.; Linke, D.; Jiao, H.; Jiang, G.; Kondratenko, E. V. Control of Coordinatively Unsaturated Zr sites in $\mathrm{ZrO}_{2}$ for Efficient C-H Bond Activation. Nat. Commun. 2018, 9, No. 3794.

(25) Otroshchenko, T. P.; Rodemerck, U.; Linke, D.; Kondratenko, E. V. Synergy Effect between $\mathrm{Zr}$ and $\mathrm{Cr}$ Active Sites in binary $\mathrm{CrZrO}_{\mathrm{x}}$ or supported $\mathrm{CrO}_{x} / \mathrm{LaZrO}_{\mathrm{x}}$ : Consequences for Catalyst Activity, Selectivity and Durability in Non-Oxidative Propane Dehydrogenation. J. Catal. 2017, 356, 197-205.

(26) Han, S.; Zhao, Y.; Otroshchenko, T.; Zhang, Y.; Zhao, D.; Lund, H.; Vuong, T. H.; Rabeah, J.; Bentrup, U.; Kondratenko, V. A.; Rodemerck, U.; Linke, D.; Gao, M.; Jiao, H.; Jiang, G.; Kondratenko, E. V. Unraveling the Origins of the Synergy Effect between $\mathrm{ZrO}_{2}$ and $\mathrm{CrO}_{\mathrm{x}}$ in Supported $\mathrm{CrZrO}_{\mathrm{x}}$ for Propene Formation in Nonoxidative Propane Dehydrogenation. ACS Catal. 2020, 10, 1575-1590.

(27) Otroshchenko, T.; Bulavchenko, O.; Thanh, H. V.; Rabeah, J.; Bentrup, U.; Matvienko, A.; Rodemerck, U.; Paul, B.; Kraehnert, R.; Linke, D.; Kondratenko, E. V. 
Controlling Activity and Selectivity of Bare $\mathrm{ZrO}_{2}$ in Non-Oxidative Propane

Dehydrogenation. Appl. Catal., A. 2019, 585, 117189.

(28) Otroshchenko, T.; Radnik, J.; Schneider, M.; Rodemerck, U.; Linke, D.;

Kondratenko, E. V. Bulk Binary $\mathrm{ZrO}_{2}$-based Oxides as Highly Active Alternative-Type

Catalysts for Non-Oxidative Isobutane Dehydrogenation. Chem. Commun. 2016, 52, 8164-8167.

(29) Ren, Y.; Zhang, F.; Hua, W.; Yue, Y.; Gao, Z. ZnO Supported on High Silica HZSM5 as New Catalysts for Dehydrogenation of Propane to Propene in the Presence of $\mathrm{CO}_{2}$.

Catal. Today. 2009, 148, 316-322.

(30) Chen, C.; Hu, Z.-P.; Ren, J.-T.; Zhang, S.; Wang, Z.; Yuan, Z.-Y. ZnO Supported on High-Silica HZSM-5 as Efficient Catalysts for Direct Dehydrogenation of Propane to Propylene. Mol. Catal. 2019, 476, 110508.

(31) A. Zimina, K. D.; M. A. Denecke, D. E. D.; E. Huttel, H. L.; S. Mangold, T. P.; J. Rothe, T. S.; R. Steininger, T. V.; Grunwaldt, H. G. a. J.-D. CAT-ACT—A New Highly 
Versatile X-ray Spectroscopy Beamline for Catalysis and Radionuclide Science at the KIT Synchrotron Light Facility ANKA. Rev. Sci. Instrum. 2017, 88, 113113.

(32) Ravel, B.; Newville, M. ATHENA, ARTEMIS, HEPHAESTUS: Data Analysis for Xray Absorption Spectroscopy using IFEFFIT. J. Synchrotron Raiat. 2005, 12, 537-541.

(33) Borowski, M. Size Determination of Small Cu-Clusters by EXAFS. J. Phys. IV France. 1997, 7, C2-259-C2-260.

(34) Perezramirez, J.; Kondratenko, E. Evolution, Achievements, and Perspectives of the TAP Technique. Catal. Today. 2007, 121, 160-169.

(35) Morgan, K.; Maguire, N.; Fushimi, R.; Gleaves, J. T.; Goguet, A.; Harold, M. P.; Kondratenko, E. V.; Menon, U.; Schuurman, Y.; Yablonsky, G. S. Forty Years of Temporal Analysis of Products. Catal. Sci. Technol. 2017, 7, 2416-2439.

(36) John T. Gleaves, G. S. Y.; Phungphai Phanawadee, Y. S. TAP-2: An Interrogative Kinetics Approach. Appl. Catal., A. 1997, 160, 55-88. 
(37) Shukla, S.; Seal, S. Mechanisms of Room Temperature Metastable Tetragonal Phase Stabilisation in Zirconia. Int. Mater. Rev. 2005, 50, 45-64.

(38) J. A. van Bokhoven, C. L. X-Ray Absorption and X-Ray: Theory and Applications. John Wiley \& Sons, Ltd.,. 2016, ISBN 978-1-118-84423-6.

(39) Wenzhong Zhang, H. W.; Yuanyan Liao, Y. Y. Acidity Generation on Mechanically Mixed $\mathrm{ZrO}_{2}-\mathrm{ZnO}$ catalysts. Catal. Lett. 1993, 20, 243-250.

(40) Velu, S.; Suzuki, K.; Gopinath, C. S.; Yoshida, H.; Hattori, T. XPS, XANES and EXAFS Investigations of $\mathrm{CuO} / \mathrm{ZnO} / \mathrm{Al}_{2} \mathrm{O}_{3} / \mathrm{ZrO}_{2}$ Mixed Oxide Catalysts. Phys. Chem. Chem. Phys. 2002, 4, 1990-1999.

(41) Christine Bozo, N. G.; Edouard Garbowski, M. P. Combustion of Methane on $\mathrm{CeO}_{2-}$ $\mathrm{ZrO}_{2}$ Based Catalysts. Catal. Today. 2000, 59, 33-45.

(42) Baylon, R. A. L.; Sun, J.; Kovarik, L.; Engelhard, M.; Li, H.; Winkelman, A. D.; Wang, Y. Structural Identification of $\mathrm{Zn}_{x} \mathrm{Zr}_{y} \mathrm{O}_{z}$ Catalysts for Cascade Aldolization and SelfDeoxygenation Reactions. Appl. Catal., B. 2018, 234, 337-346. 
(43) Biesinger, M. C.; Lau, L. W. M.; Gerson, A. R.; Smart, R. S. C. Resolving Surface Chemical States in XPS Analysis of First Row Transition Metals, Oxides and Hydroxides: Sc, Ti, V, Cu and Zn. Appl. Surf. Sci. 2010, 257, 887-898.

(44) Manríquez, M. E.; López, T.; Gómez, R.; Navarrete, J. Preparation of $\mathrm{TiO}_{2}-\mathrm{ZrO}_{2}$ Mixed Oxides with Controlled Acid-Basic Properties. J. Mol. Catal. A. Chem. 2004, 220, 229-237.

(45) Busca, G. The Surface Acidity of Solid Oxides and Its Characterization by IR Spectroscopic Methods. An Attempt at Systematization. Phys. Chem. Chem. Phys. 1999,

$1,723-736$

(46) M. Daturi, C. B.; J. C. Lavalley, G. B. Surface FTIR Investigations on $\mathrm{Ce}_{x} \mathrm{Zr}_{1-\mathrm{x}} \mathrm{O}_{2}$ System. Surf. Interface Anal. 2000, 30, 273-277.

(47) Busca, G. Spectroscopic Characterization of the Acid Properties of Metal Oxide Catalysts. Catal. Today. 1998, 41, 191-206. 
(48) Zhang, Y.; Chen, C.; Lin, X.; Li, D.; Chen, X.; Zhan, Y.; Zheng, Q. CuO/ZrO 2

Catalysts for Water-Gas Shift Reaction: Nature of Catalytically Active Copper Species.

Int. J. Hydrogen Energy. 2014, 39, 3746-3754.

(49) Kouva, S.; Honkala, K.; Lefferts, L.; Kanervo, J. Review: Monoclinic Zirconia, Its Surface Sites and Their Interaction with Carbon Monoxide. Catal. Sci. Technol. 2015, 5, 3473-3490.

(50) Huaqing Zhu, Z. Q.; Wenjuan Shan, W. S.; Wang, J. Pd/CeO ${ }_{2}-\mathrm{TiO}_{2}$ Catalyst for $\mathrm{CO}$ Oxidation at Low Temperature: A TPR Study with $\mathrm{H}_{2}$ and $\mathrm{CO}$ as Reducing Agents. J. Catal. 2004, 225, 267-277.

(51) Ashok, J.; Ang, M. L.; Kawi, S. Enhanced Activity of $\mathrm{CO}_{2}$ Methanation over $\mathrm{Ni} / \mathrm{CeO}_{2}-\mathrm{ZrO}_{2}$ Catalysts: Influence of Preparation Methods. Catal. Today. 2017, 281, 304311.

(52) Mugniery, X.; Chafik, T.; Primet, M.; Bianchi, D. Characterization of the Sites Involved in the Adsorption of $\mathrm{CO}$ on $\mathrm{ZrO}_{2}$ and $\mathrm{ZnO} / \mathrm{ZrO}_{2}$ Methanol Synthesis Aerogel Catalysts. Catal. Today. 1999, 52, 15-22. 
(53) Shee, D.; Sayari, A. Light Alkane Dehydrogenation over Mesoporous $\mathrm{Cr}_{2} \mathrm{O}_{3} / \mathrm{Al}_{2} \mathrm{O}_{3}$

Catalysts. Appl. Catal., A. 2010, 389, 155-164.

(54) Węgrzyniak, A.; Rokicińska, A.; Hędrzak, E.; Michorczyk, B.; Zeńczak-Tomera, K.;

Kuśtrowski, P.; Michorczyk, P. High-Performance $\mathrm{Cr}-\mathrm{Zr}-\mathrm{O}$ and $\mathrm{Cr}-\mathrm{Zr}-\mathrm{K}-\mathrm{O}$ Catalysts

Prepared by Nanocasting for Dehydrogenation of Propane to Propene. Catal. Sci.

Technol. 2017, 7, 6059-6068.

(55) Li, P.-P.; Lang, W.-Z.; Xia, K.; Luan, L.; Yan, X.; Guo, Y.-J. The Promotion Effects

of Ni on the Properties of Cr/Al Catalysts for Propane Dehydrogenation Reaction. Appl.

Catal., A. 2016, 522, 172-179.

(56) Searles, K.; Siddiqi, G.; Safonova, O. V.; Copéret, C. Silica-Supported Isolated Gallium Sites as Highly Active, Selective and Stable Propane Dehydrogenation Catalysts.

Chem. Sci. 2017, 8, 2661-2666.

(57) Xu, B.; Zheng, B.; Hua, W.; Yue, Y.; Gao, Z. Support Effect in Dehydrogenation of Propane in the Presence of $\mathrm{CO}_{2}$ over Supported Gallium Oxide Catalysts. J. Catal. 2006, $239,470-477$. 
(58) Zheng, B.; Hua, W.; Yue, Y.; Gao, Z. Dehydrogenation of Propane to Propene over

Different Polymorphs of Gallium Oxide. J. Catal. 2005, 232, 143-151.

(59) Chen, C.; Sun, M.; Hu, Z.; Ren, J.; Zhang, S.; Yuan, Z.-Y. New Insight into the Enhanced Catalytic Performance of ZnPt/HZSM-5 Catalysts for Direct Dehydrogenation of Propane to Propylene. Catal. Sci. Technol. 2019, 9, 1979-1988.

(60) Liu, G.; Zhao, Z.-J.; Wu, T.; Zeng, L.; Gong, J. Nature of the Active Sites of $\mathrm{VO}_{x} / \mathrm{Al}_{2} \mathrm{O}_{3}$ Catalysts for Propane Dehydrogenation. ACS Catal. 2016, 6, 5207-5214.

(61) Olsbye, U.; Virnovskaia, A.; Prytz, Ø.; Tinnemans, S. J.; Weckhuysen, B. M. Mechanistic Insight in the Ethane Dehydrogenation Reaction over $\mathrm{Cr} / \mathrm{Al}_{2} \mathrm{O}_{3}$ Catalysts. Catal. Lett. 2005, 103, 143-148.

(62) Gascón, J.; Téllez, C.; Herguido, J.; Menéndez, M. Propane Dehydrogenation over A $\mathrm{Cr}_{2} \mathrm{O}_{3} / \mathrm{Al}_{2} \mathrm{O}_{3}$ Catalyst: Transient Kinetic Modeling of Propene and Coke Formation. Appl. Catal., A. 2003, 248, 105-116. 
(63) Cutrufello, M. G.; De Rossi, S.; Ferino, I.; Monaci, R.; Rombi, E.; Solinas, V. Preparation, Characterisation and Activity of Chromia-Zirconia Catalysts for Propane Dehydrogenation. Thermo. Acta. 2005, 434, 62-68.

(64) Iglesias-Juez, A.; Beale, A. M.; Maaijen, K.; Weng, T. C.; Glatzel, P.; Weckhuysen, B. M. A Combined in Situ Time-Resolved UV-Vis, Raman and High-Energy Resolution X-ray Absorption Spectroscopy Study on the Deactivation Behavior of Pt and PtSn Propane Dehydrogenation Catalysts under Industrial Reaction Conditions. J. Catal. 2010, $276,268-279$.

(65) Goetze, J.; Meirer, F.; Yarulina, I.; Gascon, J.; Kapteijn, F.; Ruiz-Martinez, J.;

Weckhuysen, B. M. Insights Into the Activity and Deactivation of the Methanol-to-Olefins

Process over Different Small-Pore Zeolites As Studied with Operando UV-vis Spectroscopy. ACS Catal. 2017, 7, 4033-4046.

(66) Nijhuis, T. A.; Tinnemans, S. J.; Visser, T.; Weckhuysen, B. M. Towards Real-Time Spectroscopic Process Control for the Dehydrogenation of Propane over Supported Chromium Oxide Catalysts. Chem. Eng. Sci. 2004, 59, 5487-5492. 
(67) Harlin, M. E.; Niemi, V. M.; Krause, A. O. I.; Weckhuysen, B. M. Effect of Mg and

$\mathrm{Zr}$ Modification on the Activity of $\mathrm{VO}_{x} / \mathrm{Al}_{2} \mathrm{O}_{3}$ Catalysts in the Dehydrogenation of Butanes.

J. Catal. 2001, 203, 242-252.

(68) Miguel, S. R. d.; Castro, A. A.; Scelza, O. A.; Soria, J. Effect of the Addition of Alkali

Metals on the Metallic Phase of $\mathrm{Pt}_{/} \mathrm{Al}_{2} \mathrm{O}_{3}$ Catalysts. Catal. Lett. 1995, 32, 281-291.

(69) Sokolov, S.; Bychkov, V. Y.; Stoyanova, M.; Rodemerck, U.; Bentrup, U.; Linke, D.;

Tyulenin, Y. P.; Korchak, V. N.; Kondratenko, E. V. Effect of $\mathrm{VO}_{\mathrm{x}}$ Species and Support on

Coke Formation and Catalyst Stability in Nonoxidative Propane Dehydrogenation.

ChemCatChem. 2015, 7, 1691-1700. 


\section{TOC}

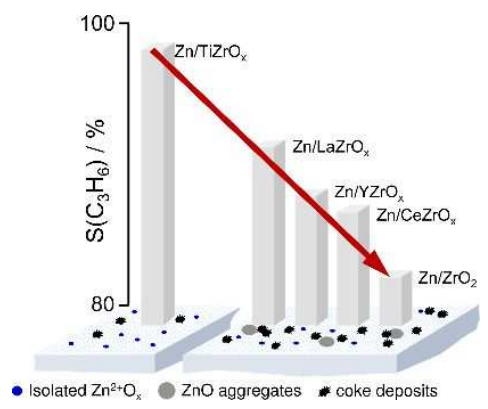

16

17

18

19

20

21

22

23

24

25

26

27

28

29

30

31

32

33

34

35

36

37

38

39

40

41

42

43

44

45

46

47

48

49

50

51

52

53

54

55

56

57

58

59

60

ACS Paragon Plus Environment 


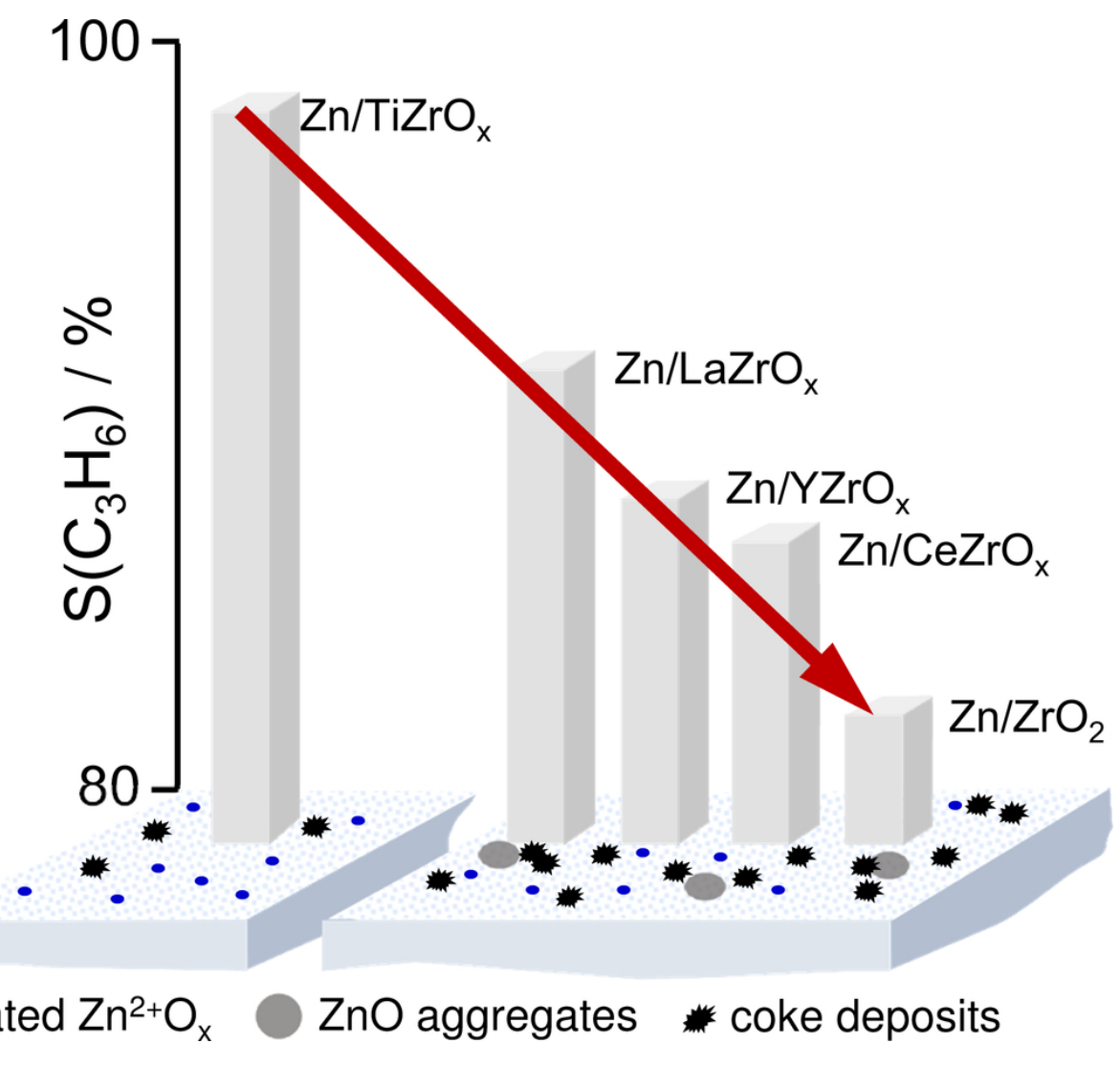

$47 \times 38 \mathrm{~mm}(600 \times 600 \mathrm{DPI})$ 